Louisiana State University

LSU Digital Commons

Faculty Publications

Department of Geology and Geophysics

$9-1-2005$

\title{
Pulsed subduction accretion and tectonic erosion reconstructed since 2.5 Ma from the tephra record offshore Costa Rica
}

\author{
Peter D. Clift \\ University of Aberdeen \\ Lui Heung Chan \\ Louisiana State University \\ Jerzy Blusztajn \\ Woods Hole Oceanographic Institution \\ Graham D. Layne \\ Woods Hole Oceanographic Institution \\ Miriam Kastner \\ Scripps Institution of Oceanography
}

See next page for additional authors

Follow this and additional works at: https://digitalcommons.Isu.edu/geo_pubs

\begin{abstract}
Recommended Citation
Clift, P., Chan, L., Blusztajn, J., Layne, G., Kastner, M., \& Kelly, R. (2005). Pulsed subduction accretion and tectonic erosion reconstructed since $2.5 \mathrm{Ma}$ from the tephra record offshore Costa Rica. Geochemistry, Geophysics, Geosystems, 6 (9) https://doi.org/10.1029/2005GC000963
\end{abstract}

This Article is brought to you for free and open access by the Department of Geology and Geophysics at LSU Digital Commons. It has been accepted for inclusion in Faculty Publications by an authorized administrator of LSU Digital Commons. For more information, please contact ir@lsu.edu. 
Authors

Peter D. Clift, Lui Heung Chan, Jerzy Blusztajn, Graham D. Layne, Miriam Kastner, and Robyn K. Kelly 


\title{
Pulsed subduction accretion and tectonic erosion reconstructed since $2.5 \mathrm{Ma}$ from the tephra record offshore Costa Rica
}

\author{
Peter D. Clift \\ Department of Geology and Petroleum Geology, University of Aberdeen, Meston Building, Kings College, Aberdeen \\ AB24 3UE, UK (p.clift@abdn.ac.uk)
}

\section{Lui-Heung Chan}

Department of Geology and Geophysics, Louisiana State University, Baton Rouge, Louisiana 70803, USA

\section{Jerzy Blusztajn and Graham D. Layne}

Department of Geology and Geophysics, MS\#22, Woods Hole Oceanographic Institution, Woods Hole, Massachusetts 02543, USA

\section{Miriam Kastner}

Scripps Institution of Oceanography, University of California, San Diego, 9500 Gilman Drive, La Jolla, California 92093-0208, USA

\section{Robyn K. Kelly}

CTL Environmental Services, 24404 South Vermont Avenue \#307, Harbor City, California 90710, USA

[1] Tephra layers recovered by Ocean Drilling Program from the forearc and trench regions offshore the Nicoya Peninsula of Costa Rica allow the temporal evolution of the volcanic arc to be reconstructed since 2.5 Ma. Major and trace element analyses by microprobe methods reveal a dominant tholeiitic character and a provenance in the Costa Rican area. The tephra show long-term coherent variability in geochemistry. One tephra dated at $1.45 \mathrm{Ma}$ shows minimum values in $\varepsilon_{\mathrm{Nd}}$ and maximum $\mathrm{Li} / \mathrm{Y}$ consistent with very high degrees of sediment recycling at this time. However, overall $\mathrm{Li} / \mathrm{Y}$ and $\delta^{7} \mathrm{Li}$ increase with $\mathrm{SiO}_{2}$ content, suggesting addition of heavy Li through forearc tectonic erosion and crustal assimilation. Peak values in $\delta^{7} \mathrm{Li}$ starting at $1.45 \mathrm{Ma}$ and lasting $\sim 0.5 \mathrm{~m}$.y. indicate enhanced tectonic erosion of the forearc possibly caused by subduction of a seamount at $1.45 \mathrm{Ma}$. The tephra record indicates significant temporal variability in terms of sediment subduction, reconciling the geologic evidence for long-term tectonic erosion and geochemical evidence for recent sediment accretion in the modern Central American arc.

Components: 14,154 words, 16 figures, 2 tables.

Keywords: Costa Rica; subduction; geochemistry; tephra.

Index Terms: 8404 Volcanology: Volcanoclastic deposits; 8413 Volcanology: Subduction zone processes (1031, 3060, 3613, 8170); 9355 Geographic Location: Pacific Ocean.

Received 8 March 2005; Revised 5 August 2005; Accepted 5 August 2005; Published 27 September 2005.

Clift, P. D., L.-H. Chan, J. Blusztajn, G. D. Layne, M. Kastner, and R. K. Kelly (2005), Pulsed subduction accretion and tectonic erosion reconstructed since 2.5 Ma from the tephra record offshore Costa Rica, Geochem. Geophys. Geosyst., 6, Q09016, doi:10.1029/2005GC000963. 


\section{Introduction}

[2] Studies of petrogenesis in subduction zones have typically focused on estimating the relative contributions made by mantle melting, sediment subduction, and crustal recycling in forming new arc magmas. Central America has been a focus of such studies because of the significant along-strike variations in volcanic chemistry that have been linked in differences in the basement composition, rate and direction of subduction, as well as trench sediment compositions [e.g., Carr et al., 1990, 2003; Reagan et al., 1994; Leeman et al., 1994; Patino et al., 2000; Ruepke et al., 2002]. A complicating factor in understanding the magmatic processes is accounting for temporal variation in volcanism. Most studies have to assume that the modern output is representative of the net production over longer periods of geologic time, but this need not be true if the tectonic state of the margin evolves significantly.

[3] In the Costa Rica area two different views of mass flux have been formulated. Tectonicists have shown that the margin and trench slope are in a state of long-term subsidence and presumed mass loss due to subduction erosion [Meschede et al., 1999; Vannucchi et al., 2001, 2003]. In contrast, geochemical data from the arc indicates that the sedimentary cover in the modern trench cannot presently be contributing significantly to petrogenesis, implying that the sediment is being offscraped and accreted to the margin [Valentine et al., 1997; Morris et al., 2002]. Initial geophysical surveys had proposed that the Costa Rican forearc was largely composed of an accretionary wedge [Shipley et al., 1992], yet drilling of the region by Ocean Drilling Program (ODP) Leg 170 demonstrated that in fact the slope was formed of an extension to the onshore Nicoya Complex, mantled by a sedimentary apron of mass wasted continental detritus [Kimura et al., 1997]. Although the ODP drilling ruled out the possibility of much accretion of oceanic sediments at the toe of the forearc wedge during the recent geologic past, it was not able to show whether sediments have been transferred to the overriding plate by underplating at greater depths. Clearly both models advocating accretion and erosion cannot be correct over the same timescales.

[4] In this study we reconstruct the magmatic evolution of the Costa Rican section of the Central American arc in order to assess variability in the degree of sediment subduction in the recent geo- logic past. We employ a series of geochemical proxies to assess how the arc has changed character through time, using major and trace elements to be place broad constraints on the petrogenesis, but then applying $\mathrm{Nd}$ and $\mathrm{Li}$ isotopes to track the flux of these elements through the subduction zone in order to constrain the changing influences of fluids and sediments on magma formation.

\section{Geologic Setting}

[5] The samples considered in this study were cored from the forearc and trench regions offshore the Nicoya Peninsular of Costa Rica during ODP Legs 170 and 205 (Figure 1) [Kimura et al., 1997; Morris et al., 2003]. Lying downwind of the arc volcanoes in Costa Rica they are presumed to sample the explosive end-member magmatism in this part of the arc. The Central American arc is built on a basement of Caribbean plate oceanic plateau crust and represents the product of longlived subduction toward the east [Hauff et al., 1997; Sinton et al., 1997]. The character of the forearc offshore has been the subject of extensive work. Initial seismic work of the wedge-shaped forearc suggested the presence of a large accretionary complex [Shipley et al., 1992], yet drilling and further seismic analysis showed that the forearc is probably composed of rocks similar to the igneous oceanic rocks cropping out along the coast [Shipley et al., 1992; Kimura et al., 1997; von Huene et al., 2000]. There is no evidence for a large sediment accretionary complex in the region, although a small sediment prism $(<10 \mathrm{~km}$ wide $)$ is located next to the trench. Although there seems to be little evidence for long-term accretion it is possible that accretion of trench sediment could have been occurring in the recent past. Seismic images show that the entire sediment cover of the oceanic plate is currently underthrust beneath the margin and that the frontal sediment prism can store very little, if any, of the incoming material [Kimura et al., 1997; Christeson et al., 1999; McIntosh and Sen, 2000; Moritz et al., 2000; Ranero et al., 2000; von Huene et al., 2000]. However, it is less clear whether sediment might be added to the margin at greater depths in the subduction zone.

[6] The geology of the margin is strongly controlled by the nature of the subducting plate, which is dominated by the Cocos Ridge to the SE of the Nicoya Peninsular (Figure 1) [Barckhausen et al., 2001]. The Cocos Ridge is considered to be a product of the Galapagos hot spot. Convergence rates are around $8 \mathrm{~cm} / \mathrm{yr}$ offshore Costa Rica and 


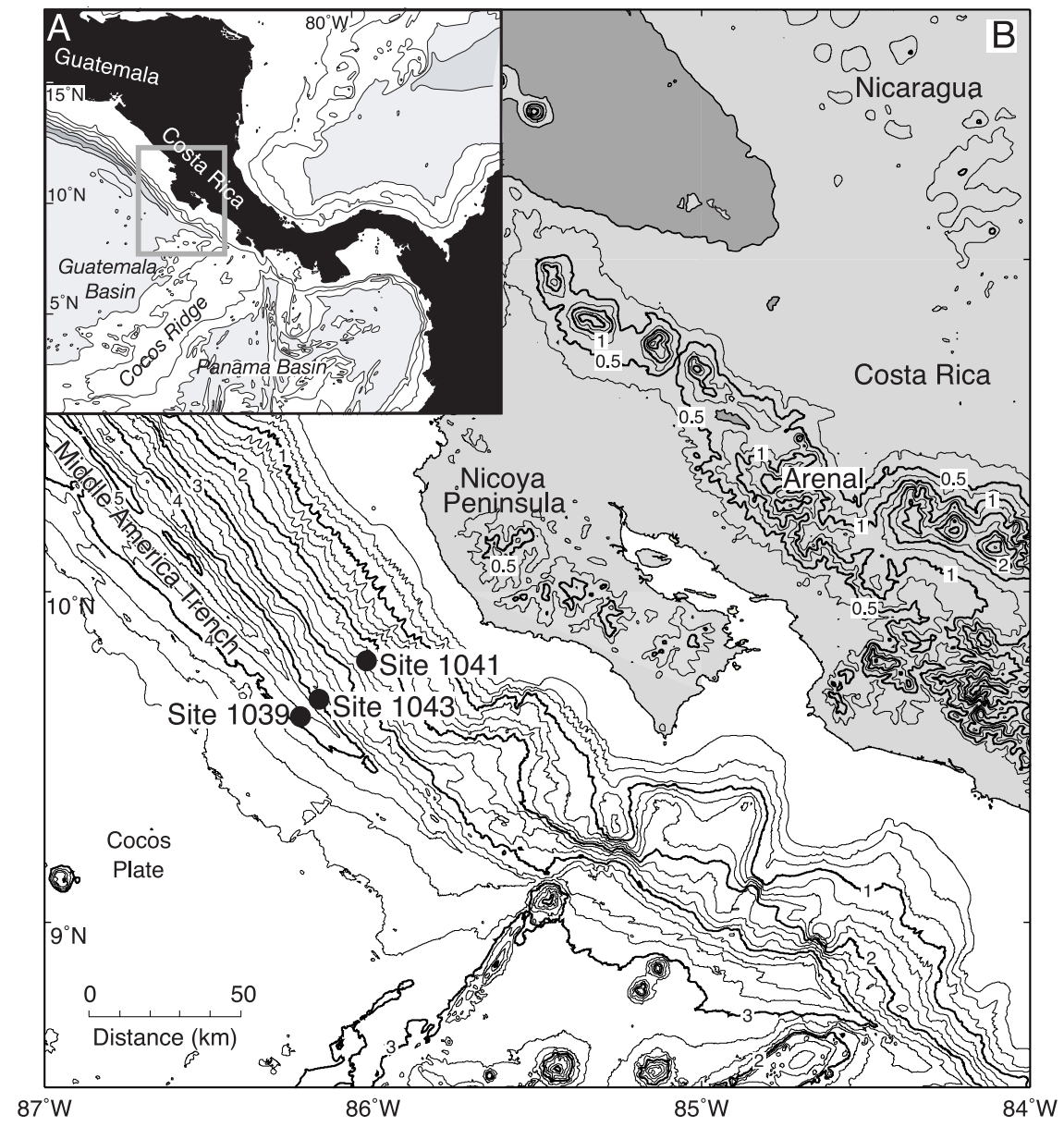

Figure 1. (a) Map of Central American region showing the location of the study area relative to the Cocos Ridge. (b) The region depicted by the gray box in Figure 1a. Bathymetric map of the Middle America Trench offshore the Nicoya Peninsula of Costa Rica. Water depths and elevations are shown in kilometers. ODP Sites 1041 and 1043 lie on the trench slope, with ODP Site 1039 located close to the trench axis on the subducting plate.

bring crust formed at the East Pacific Rise (EPR) and Cocos-Nazca spreading center (CNS) into the trench. Crustal ages are $\sim 24 \mathrm{Ma}$ in the EPR section and as old as $22.7 \mathrm{Ma}$ south in the CNS crust. Magnetic anomalies have been used to map a tectonic boundary separating the two types of lithosphere $\sim 20 \mathrm{~km}$ south of the study area [Barckhausen et al., 2001].

[7] The sedimentary cover to the subducting EPR crust varies in thickness depending on the basement topography but is never very thick, averaging around $400 \mathrm{~m}$ thick in the trench near ODP Site 1039 (Figure 1). The stratigraphy on the subducting plate comprises Miocene pelagic chalks with occasional mafic tephras overlain by Pliocene silty clays and finally by Pleistocene diatom oozes [Kimura et al., 1997]. Siliceous tephra layers are interspersed into the diatom oozes at ODP Site 1039, providing a record of explosive volcanism.
An age framework can be imposed on the stratigraphy through a combination of biostratigraphic and paleomagnetic methods [Kimura et al., 1997]. A small number of additional tephra were considered in this study from ODP Sites 1041 and 1043 located on the forearc slope [Morris et al., 2003]. In this area the forearc sedimentary cover comprises claystones with minor amounts of sand and silt, forming a mass-wasted apron overlying the igneous basement and the small accretionary complex at the toe. Despite the erosive reworking a number of tephra are preserved in this area and can be dated through biostratigraphy, allowing them to form part of a coherent regional volcanic record.

\section{Character of the Tephra Record}

[8] Study of the marine tephra record has advantages and disadvantages compared to work on 


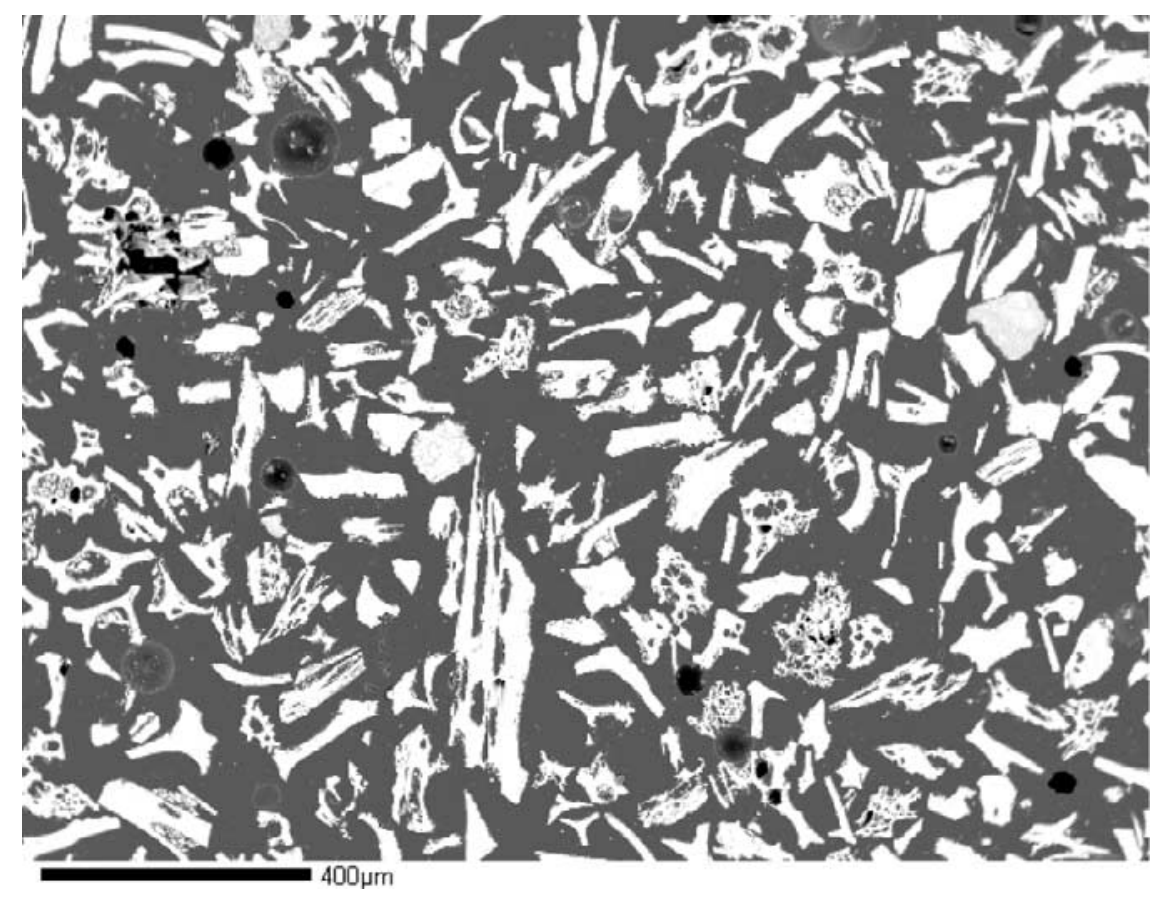

Figure 2. Backscatter electron microscope image of Sample 1039B-10H-5, $30 \mathrm{~cm}$ showing the type of material analyzed in this study, principally comprising vesicular shards of volcanic glass. Scale bar represents $400 \mu \mathrm{m}$.

the arc volcanoes themselves when the goal is to reconstruct the temporal evolution of arc magmatism. The provenance of recent lava sequences exposed on land is usually clear, although determining the age of extrusion often requires time-consuming and expensive radioactive dating methods. In contrast, marine airfall tephra are always in the correct stratigraphic order and can be readily dated using biostratigraphy with reference to an established timescale. However, determining the source of the tephra can sometimes be a problem in interpreting their chemistry, because tephra can be blown far down-wind, or along strike of an arc system. This is not expected be too disruptive in this study because the prevailing winds tend to carry material offshore to the west, limiting possible sources. The young age of the tephra considered here means that they have not moved far from their original site of deposition, again favoring the Costa Rican section of the arc as the source. Furthermore, the chemistry of the Central American arc changes significantly along strike, allowing provenance to be constrained by comparing onshore and tephra compositions [e.g., Carr et al., 1990; Reagan et al., 1994; Leeman et al., 1994; Patino et al., 2000]. While this is a less convincing method in the geological past because the arc changes composition a match between the youngest tephra and volcanic rocks can provide a useful constraint to tephra provenance.

[9] Use of airfall ashes to reconstruct arc evolution results in a record biased in favor of the more explosive eruptions, typically the more silicic compositions. Thus ashes may provide information on periods of arc volcanism that are poorly or completely unrepresented elsewhere, because explosive eruptions are often not accompanied by a voluminous extrusive sequence located close to the center. As such the marine record provides a rather different record than that exposed on land. The tephra material is dominated by vesicular volcanic glass shards and contains only minor amounts of mafic minerals or feldspars (Figure 2). The glass shards themselves represent rapidly chilled glass that is a relatively pristine sample of the liquid composition at the time of eruption. Electron probe backscatter study shows some microphenocrysts are developed in the glass that can be avoided by probe analysis, though these are generally rare and form a small proportion of the total material. The evolved glasses that form most of the material considered here tend to favor vesicular geometries, resulting in a large surface area to volume ratio. This in turn makes them susceptible to rapid 


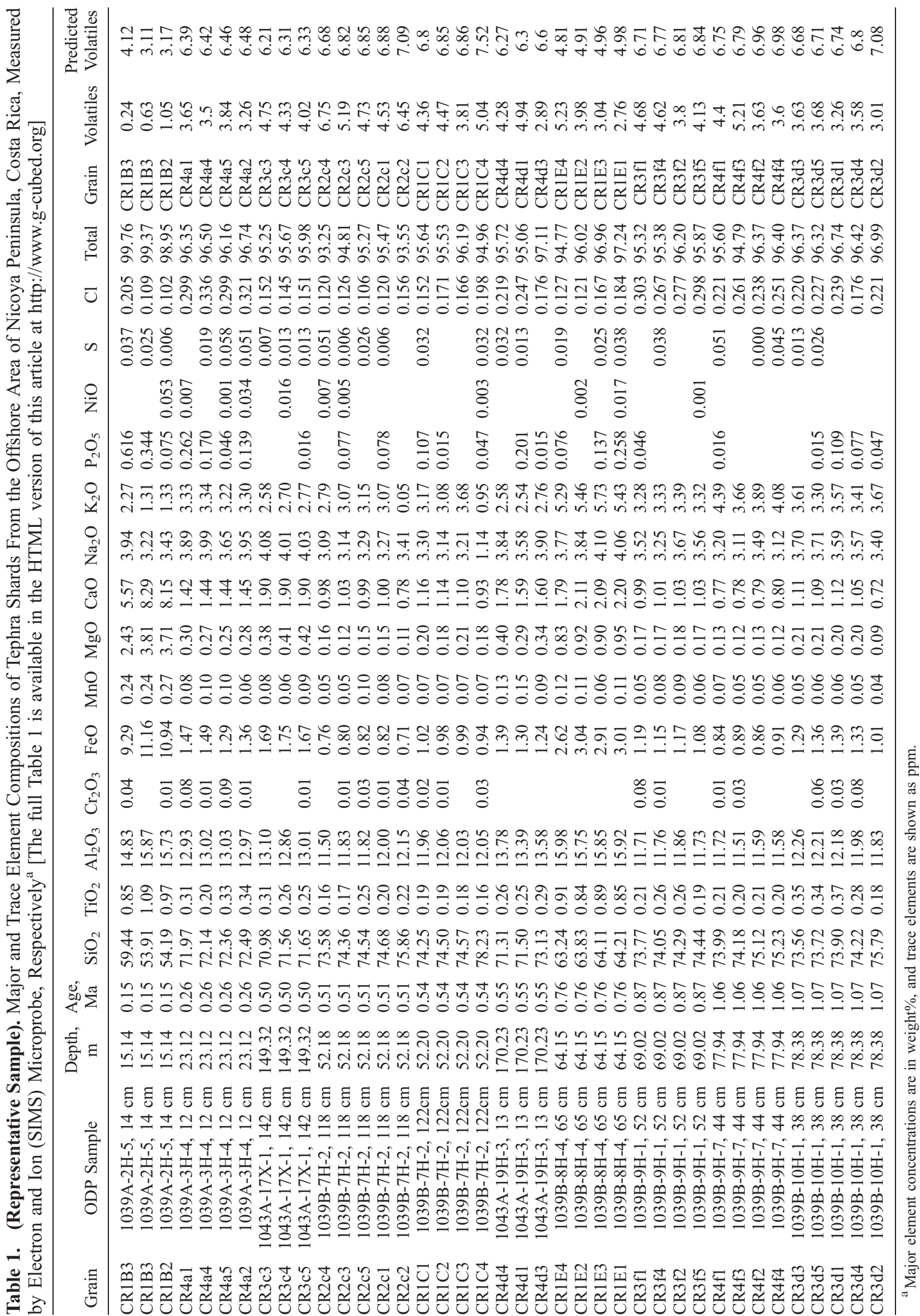


Table 2. Li and Nd Isotope Compositions of Costa Rican Tephra Measured by TIMS ${ }^{\mathrm{a}}$

\begin{tabular}{|c|c|c|c|c|c|c|c|c|c|c|}
\hline ODP Sample & $\begin{array}{c}{ }^{143} \mathrm{Nd} / \\
{ }^{144} \mathrm{Nd}\end{array}$ & $\begin{array}{l}1 \sigma \\
\text { Error }\end{array}$ & $\varepsilon_{\mathrm{Nd}}$ & $\mathrm{Li}$ & $\mathrm{Y}$ & $\delta^{7} \mathrm{Li}$ & $\begin{array}{l}\mathrm{SiO}_{2} \\
\%\end{array}$ & $\begin{array}{c}\text { Proportion } \\
\text { of } \\
\text { Sedimentary } \\
\text { Nd, } \\
\%\end{array}$ & $\begin{array}{l}\text { Proportion } \\
\text { of } \\
\text { Forearc } \\
\text { Crust, } \\
\%\end{array}$ & $\begin{array}{c}\text { Proportion } \\
\text { of } \\
\text { Mantle } \\
\text { Melt, } \\
\%\end{array}$ \\
\hline 1039A-2H-5, $14 \mathrm{~cm}$ & 0.513056 & 9 & 8.15 & 10.60 & 27.58 & 4.57 & 55.7 & 5 & 8 & 87 \\
\hline 1039A-3H-4, $12 \mathrm{~cm}$ & 0.512965 & 6 & 6.38 & 15.60 & 19.10 & 7.43 & 72.2 & 17 & 21 & 62 \\
\hline 1039B-7H-2, $122 \mathrm{~cm}$ & 0.513017 & 10 & 7.39 & 21.80 & 14.76 & 9.88 & 75.0 & 7 & 44 & 49 \\
\hline 1039B-9H-1, $52 \mathrm{~cm}$ & 0.512999 & 6 & 7.04 & 19.30 & 20.65 & 10.90 & 74.1 & 8 & 47 & 45 \\
\hline 1039B-10H-1, $38 \mathrm{~cm}$ & 0.513025 & 4 & 7.55 & 17.40 & 20.61 & 13.98 & 74.2 & 0 & 78 & 22 \\
\hline 1039B-10H-5, $30 \mathrm{~cm}$ & & & & 20.20 & 15.94 & 12.73 & 74.8 & & & \\
\hline 1039B-11H-7, $38 \mathrm{~cm}$ & 0.512766 & 13 & 2.5 & 25.90 & 13.95 & 13.26 & 74.8 & 42 & 49 & 9 \\
\hline 1039B-13X-5, $30 \mathrm{~cm}$ & 0.513016 & 3 & 7.37 & 16.80 & 39.39 & 8.19 & 66.5 & 9 & 32 & 59 \\
\hline $\begin{array}{l}\text { 1039B-13X-5, } 30 \mathrm{~cm} \\
\text { (acid washed) }\end{array}$ & & & & 17.44 & 39.39 & 6.80 & 66.5 & & & \\
\hline 1039B-15X-7, $25 \mathrm{~cm}$ & 0.513006 & 4 & 7.18 & 13.50 & 36.11 & 10.21 & 69.2 & 8 & 51 & 41 \\
\hline $\begin{array}{l}\text { 1039B-15X-7, } 25 \mathrm{~cm} \\
\text { (acid washed) }\end{array}$ & & & & 11.99 & 36.11 & 9.18 & 69.2 & & & \\
\hline 1039B-16X-1, $72 \mathrm{~cm}$ & 0.512988 & 10 & 6.83 & 15.60 & 11.67 & & 74.5 & & & \\
\hline $1041 \mathrm{~A}-2 \mathrm{H}-5,50 \mathrm{~cm}$ & & & & 13.30 & 13.08 & 10.49 & 70.2 & & & \\
\hline $\begin{array}{l}\text { 1041A-2H-5, } 50 \mathrm{~cm} \\
\text { (acid washed) }\end{array}$ & & & & 12.03 & 13.08 & 10.14 & 70.2 & & & \\
\hline \multicolumn{11}{|l|}{ Costa Rican volcanoes } \\
\hline Arenal CRAR 82 & & & & 7.86 & 15.50 & 5.00 & 54.6 & & & \\
\hline Platanar CR PP7 & & & & 4.81 & 16.60 & 5.20 & 46.1 & & & \\
\hline Irazu CR IZ63-6 & & & & 9.10 & 21.70 & 6.40 & 55.2 & & & \\
\hline
\end{tabular}

${ }^{\mathrm{a}} \mathrm{SiO}_{2}$ of ODP Site $1039 / 1041$ shards are averages of the electron probe analyses. $\mathrm{Li}, \mathrm{Y}, \mathrm{SiO}_{2}$ of Costa Rican volcanoes are from Chan et al. [1999]. $\delta^{7} \mathrm{Li}$ data of Costa Rican volcanoes are from Chan et al. [2002a].

alteration during diagenesis, thus limiting the extent of the record that can be reconstructed.

\section{Sample Collection and Preparation}

[10] Samples were chosen from discrete tephra layers and were preferentially taken from the coarser grained layers where this was possible. All samples were considered to be from primary airfall deposits. Sediments were disaggregated by being mixed with water and placed in an ultrasonic bath. After this the sediments were sieved through a $63 \mu \mathrm{m}$-sized mesh and washed by a high-pressure water jet. A selection of grains from the $>63 \mu \mathrm{m}$ fraction was then mounted using epoxy in $1^{\prime \prime}$ round mounts and polished using a combination of alumina and diamond pastes. The mounts were coated in graphite prior to electron probe analysis.

[11] The tephra shards were analyzed using the JEOL 733 Superprobe at the Massachusetts Institute of Technology (MIT), USA, using a $10 \mathrm{nA}$ beam with a voltage offset of $15 \mathrm{kV}$. The shards were analyzed for a suite of major elements $\mathrm{Si}, \mathrm{Al}$, $\mathrm{Na}, \mathrm{K}, \mathrm{Ca}, \mathrm{Mg}, \mathrm{Fe}, \mathrm{P}, \mathrm{Ti}, \mathrm{Cr}, \mathrm{Cl}, \mathrm{S}$ and $\mathrm{Mn}$. The beam was defocused to a $10 \times 10 \mu \mathrm{m}$ area to reduce the loss of volatile elements, especially $\mathrm{Na}$ during analysis [Neilson and Sigurdsson, 1981].

[12] After electron probing the mounts were cleaned, coated in gold and analyzed using the Cameca ims $3 f$ ion microprobe (secondary ion mass spectrometer, SIMS) at Woods Hole Oceanographic Institution (WHOI), USA, for a suite of trace and rare earth elements. Glass grains analyzed by ion microprobe were selected to be aphyric or to contain the minimum number of phenocrysts within the available sample set. There is no way of establishing whether phenocryst phases were actually absent from the host magma of an aphyric glass fragment on eruption. Results of the major and trace element analyses are shown in Table 1. Uncertainties in the trace element analyses are 2$5 \%$ of most elements.

[13] Lithium isotope analyses were performed on whole tephra samples. The tephra were washed with distilled water to remove residual salts from the pore waters. For comparison, three shard samples were cleaned with nitric acid, $\mathrm{H}_{2} \mathrm{O}_{2}$ and methanol. The bulk samples were digested in a 


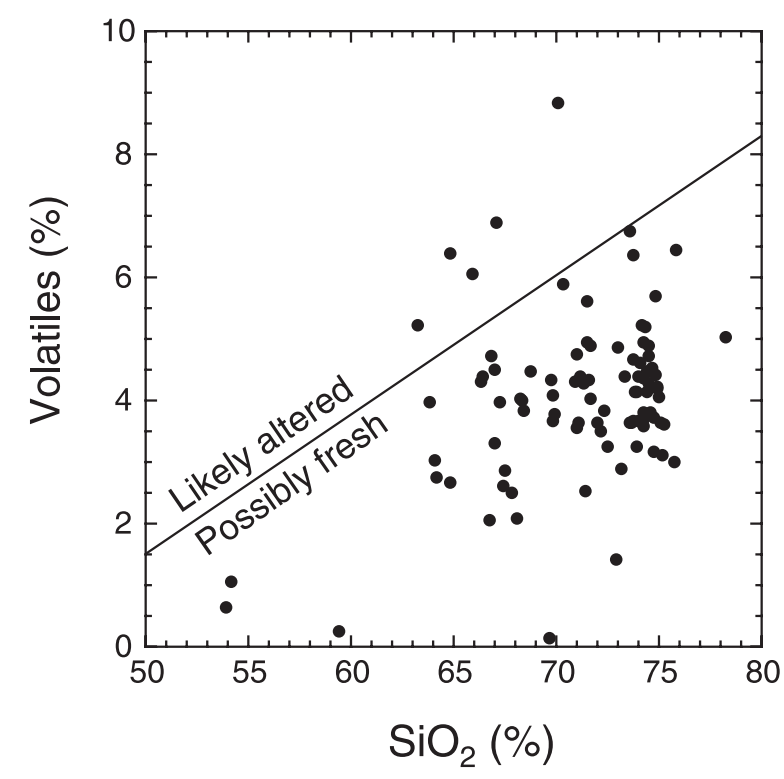

Figure 3. Diagram showing the variation in silica versus the proportion of volatiles in the tephras analyzed (estimated by $100 \%$ - total measured by major element compositions). The total proportion of magmatic volatiles increases with fractional crystallization. Points falling above the line contain more volatile than would be expected for a fresh glass and are likely altered.

mixture of double distilled $\mathrm{HF}$ and $\mathrm{HClO}_{4}$ following the procedure of Chan et al. [1992]. Li concentrations of the bulk sediments were determined by flame emission with standard additions and Y concentrations of the bulk sediments were determined by Perkin Elmer 3300 DV dual view inductively coupled plasma optical emission spectrometer (ICP-OES) at Louisiana State University (LSU). Li isotope compositions were determined by thermal ionization mass spectrometry with phosphate as the ion source [You and Chan, 1996], on the Finnigan MAT 262 thermal ionization mass spectrometer (TIMS), also at LSU. Li isotope character is expressed using $\delta^{7} \mathrm{Li}$, which is the per mil deviation of ${ }^{7} \mathrm{Li} /{ }^{6} \mathrm{Li}$ from the NIST lithium carbonate standard L-SVEC [Flesch et al., 1973] and are shown in Table 2. Repeated analysis of standard reference rocks indicates the precision of $\delta^{7} \mathrm{Li}$ to be better than $\pm 1 \%$ [Chan and Frey, 2003].

[14] $\mathrm{Nd}$ isotopes were measured from powdered whole tephra samples, identical to those analyzed for $\mathrm{Li}$ isotopes. After dissolution, $\mathrm{Nd}$ was concentrated using standard column extraction techniques, and isotopic compositions were determined on the Finnegan "Neptune" multicollector inductively coupled plasma mass spectrometer (MC-ICP-MS) at WHOI. All samples were corrected against La Jolla Nd standard ${ }^{143} \mathrm{Nd} /{ }^{144} \mathrm{Nd}=0.511847$. We calculate the parameter $\varepsilon_{\mathrm{Nd}}$ [DePaolo and Wasserburg, 1976] using a ${ }^{143} \mathrm{Nd} /{ }^{144} \mathrm{Nd}$ value of 0.512638 for the Chondritic Uniform Reservoir (CHUR) [Hamilton et al., 1983].

\section{Major Element Chemistry}

[15] Analytical totals for tephra grains were typically $2-6 \%$ less than $100 \%$, indicating the presence of volatiles in the glass. Some of the low analytical totals are related to the loss of $\mathrm{Na}$ and $\mathrm{K}$ during analysis, although this loss should not be too high as a result of the defocused beam method employed. Low analytical major element totals can arise from an indigenous volatile content in the melt or from subsequent hydration, possibly without accompanying visual evidence. Distinguishing between primary magmatic and alteration-related volatile content is difficult but important to the interpretation of water mobile element analyses, such as boron. Primary water contents in the melt may be expected to rise during crystal fractionation, since this is an incompatible component in most igneous phases [e.g., Burnham and Jahns, 1962]. Consequently it is possible to define an original magmatic trend of increasing volatile content above which any given analysis may be considered to be possibly altered [cf. Clift and Vroon, 1996]. Figure 3 shows the alteration filter applied to the tephra considered here. Although the exact slope and trend of the filter is not fixed, such an approach does allow those grains most likely to be altered to be excluded from further consideration. However, it does not guarantee the pristine character of the grains whose totals are high enough to pass this filter.

[16] The general character of the major element chemistry of the tephras is shown in Figure 4. The dominantly tholeiitic character of volcanism is shown on the $\mathrm{FeO} / \mathrm{MgO}$ versus $\mathrm{SiO}_{2}$ plot of Miyashiro [1974], where a strong relative $\mathrm{FeO}$ enrichment is plain for most analyzed shards (Figure $4 \mathrm{a}$ ). By plotting $\mathrm{K}_{2} \mathrm{O}$ against $\mathrm{SiO}_{2}$ for all glasses (Figure 4b) it may be seen that the Costa Rica tephra are mostly classified as medium to high-K tholeiites according to the scheme of Peccerillo and Taylor [1976], though overlapping into the adjacent low-K and shonshonite fields as well.

[17] The major element compositions can also be used to assess possible provenance based on the range of analyzed rocks known from onshore. In 
(A)

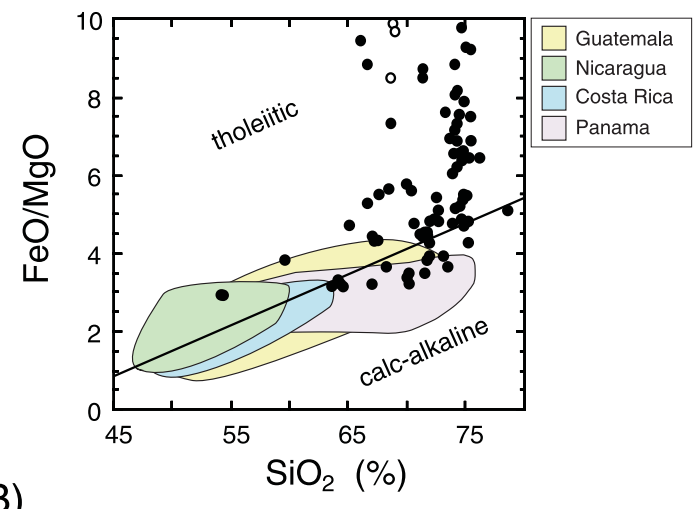

(B)

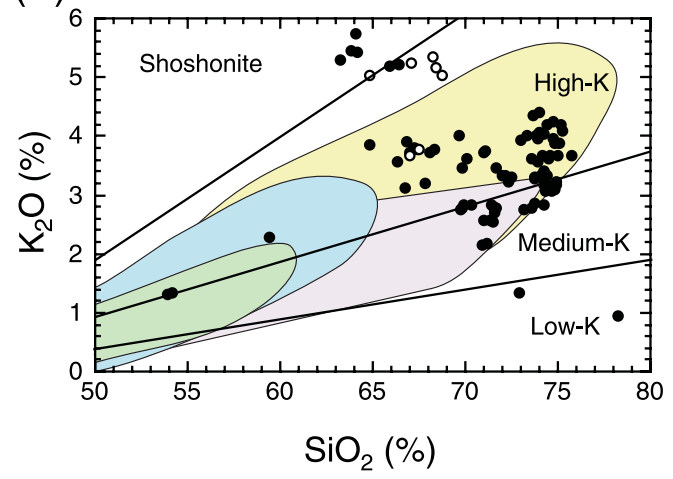

Figure 4. Major element characteristics of Costa Rica tephra glasses. (a) $\mathrm{FeO} / \mathrm{MgO}$ versus $\mathrm{SiO}_{2}$ variation diagram to show the general $\mathrm{FeO}$-enriched, tholeiitic chemistry [Miyashiro, 1974]. Central American arc lava fields are from the GEOROC compilation. Panama field is from Defant et al. [1991a, 1991b]. (b) $\mathrm{K}_{2} \mathrm{O}$ versus $\mathrm{SiO}_{2}$ diagram showing the wide range of analyzed compositions, though with a dominance of high- and medium-K lavas. Compositional fields are from Peccerillo and Taylor [1976]. Solid symbols represent arc tephra. Empty circles indicate Galapagos-derived tephra.

this study we compare tephra glass compositions with all recent lavas from Central America compiled into the GEOROC database. Significant along strike chemical variability is known [e.g., Carr, 1984; Carr et al., 1990], although because lavas by definition reflect the nonexplosive products of the arc it is not clear whether the analyzed ranges from each part of the arc are truly comparable. Known lavas from Guatemala seem to provide the best match with the tephra shards, though all Central American lavas seem to fall along the same broad line of evolution, so that it is doubtful whether such a comparison is a valid test of origin by itself, because the tephra glasses are considerably more evolved than the lavas that define the fields in Figure 4b.

[18] Figure 5 shows the temporal variability in $\mathrm{SiO}_{2}, \mathrm{FeO}$ and $\mathrm{K}_{2} \mathrm{O}$ concentrations of the Costa
Rican tephra since 2.5 Ma. The diagram shows a number of features that demonstrate significant temporal variation. The youngest tephra is the most mafic, FeO-rich and poor in $\mathrm{K}_{2} \mathrm{O}$. Other trends are visible over longer intervals. Both $\mathrm{SiO}_{2}$ decreased while $\mathrm{K}_{2} \mathrm{O}$ increased from 2.5 to $1.5 \mathrm{Ma}$. $\mathrm{K}_{2} \mathrm{O}$ subsequently decreased again after $0.8 \mathrm{Ma}$ to the present-day. $\mathrm{SiO}_{2}$ concentrations after $1.5 \mathrm{Ma}$ show generally high values until $0.15 \mathrm{Ma}$. Because the tectonic setting of Central America has not changed greatly since $2.5 \mathrm{Ma}$ there is no apparent link in these major element trends and the regional geodynamics.

\section{Trace Element Character}

[19] The trace element chemistry of the tephras can be assessed using multielement spider diagrams (Figure 6). In these plots elements are arranged so that their compatibility in mantle phases increases in either direction away from $\mathrm{Nb}$. Water mobile elements are placed on the left of the diagram, and immobile elements on the right (modified after Pearce [1983]). The element concentrations are all normalized to mid-ocean ridge basalt (N-MORB) [Sun and McDonough, 1989]. The plots share several common features, including a strong enrichment in water-mobile, incompatible elements for all glasses, likely due to flux from the subducting slab. The fact that the analyses appear similar to patterns derived from subaerial volcanic rocks from the associated arc volcanoes suggests limited remobilization of even water-mobile elements during burial diagenesis and supports the contention that these young tephra largely comprise unaltered volcanic glasses.

[20] The tephra show enrichment not only in the water mobile elements but are also elevated above $\mathrm{N}$-MORB values in some of the most incompatible, water-immobile elements. Tephra glasses of all ages form a relatively well-defined array of compositions, suggesting a consistent overall petrogenetic process. The relative enrichment in incompatible elements could reflect contamination of mantle melts by the chemically enriched crust of the Caribbean plate basement on which the arc is built, either due to subduction of enriched sediments eroded from this region or through the assimilation of crust during passage of melt to the surface.

[21] The petrogenesis of the tephra can be further assessed through examination of the rare earth elements (REE). Figure 7 shows the range of 


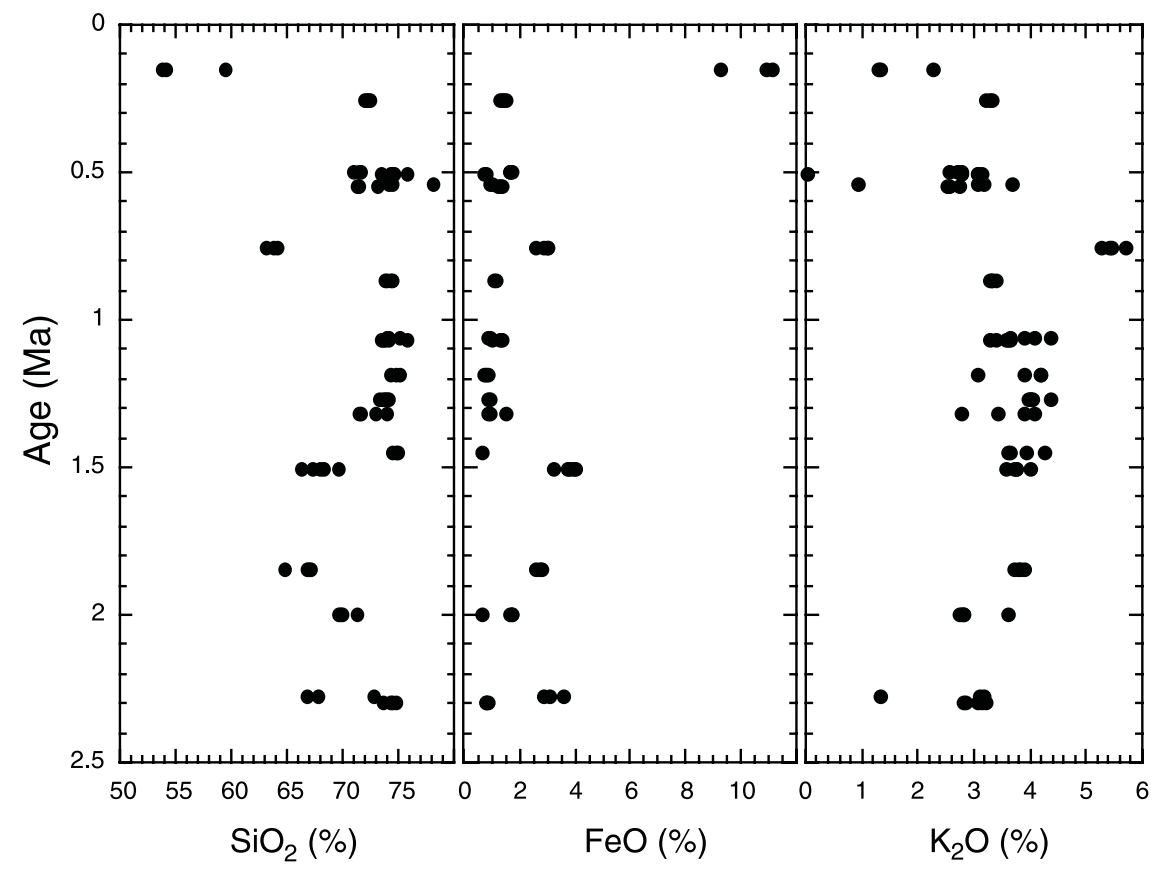

Figure 5. Diagram showing the temporal evolution in the chemistry of tephras cored on the Costa Rica forearc since $2.5 \mathrm{Ma}$. Note long-term variability and the recent sharp departure to more mafic compositions.

tephra compositions normalized against $\mathrm{C} 1$ chondrite. These diagrams demonstrate a significant range in total REE concentrations and in the slope of the REE array, though all with a relative light REE (LREE) enrichment. While the total REE content is controlled by fractional crystallization, as well as source composition and degree of partial melting, the slope of the curve is more critically dependent on source composition and mineralogy, which do not appear to have been constant since $2.5 \mathrm{Ma}$.

\subsection{Coupling of Element Groups}

[22] The relationship between REEs and high field strength elements (HFSEs) can be assessed using

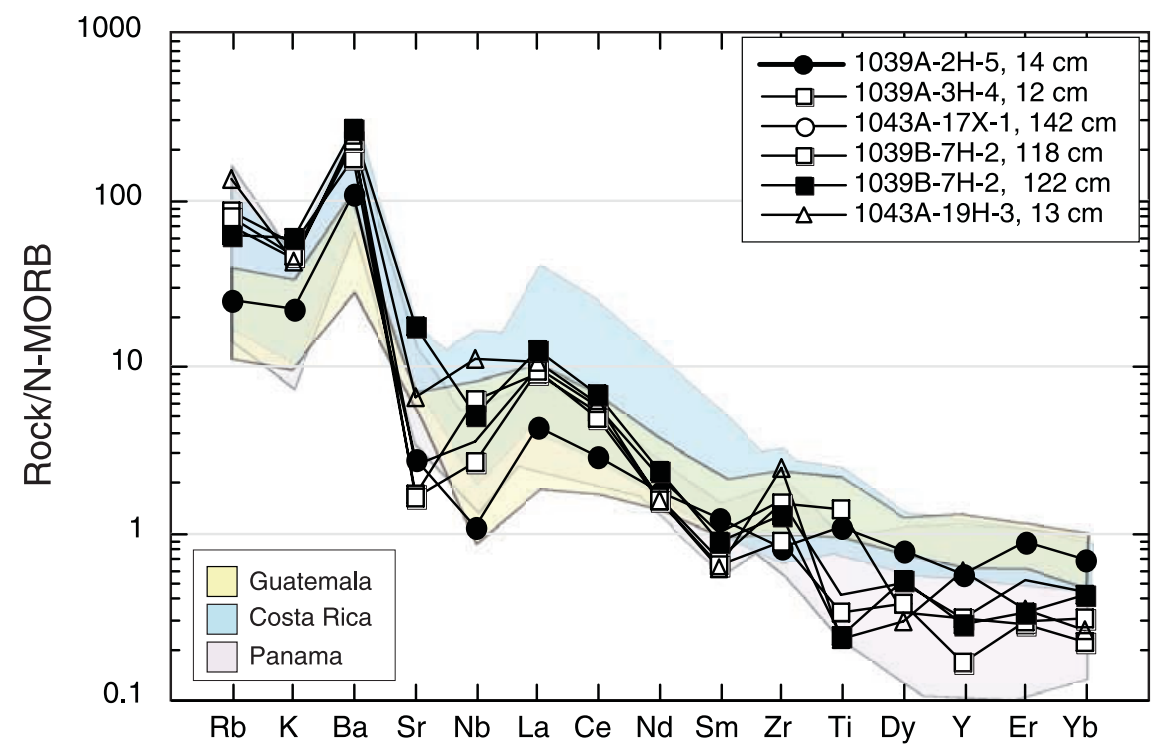

Figure 6. Multielement spider diagram for Costa Rica tephra, normalized with the N-MORB values of Sun and McDonough [1989]. Note the relative $\mathrm{Nb}$ depletion characteristic of magmatism in arc settings. Central American arc lava fields are from the GEOROC compilation. Panama field is from Defant et al. [1991a, 1991b]. 


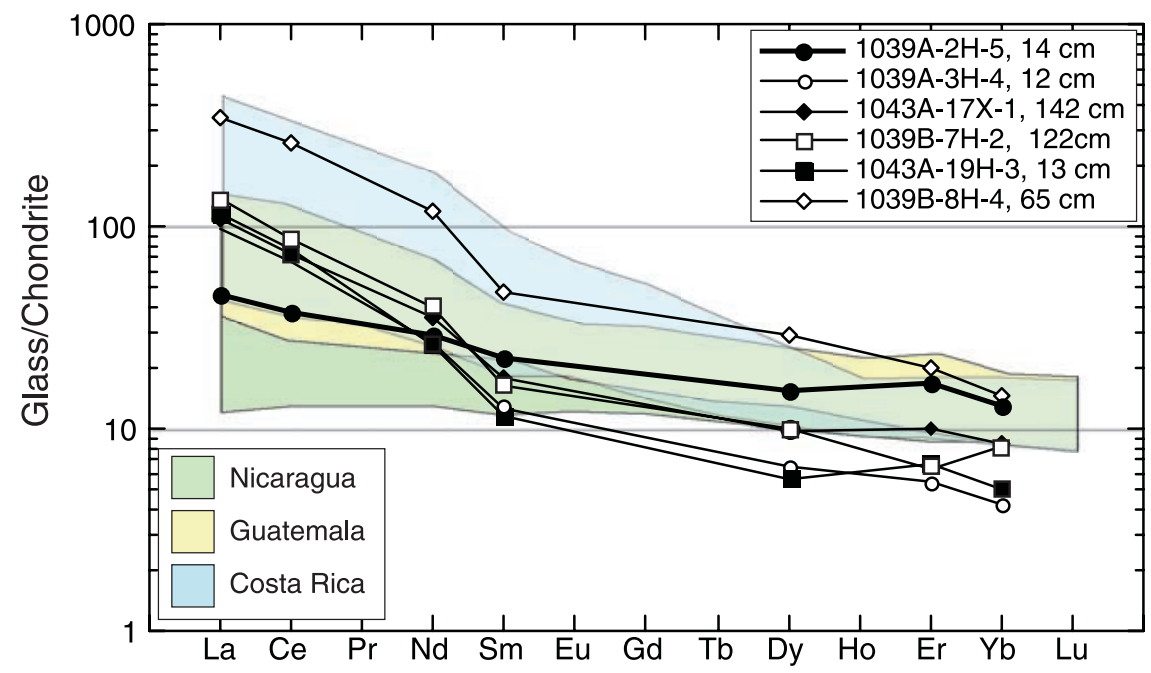

Figure 7. Chondrite-normalized rare earth element diagram for Costa Rica tephra. Chondrite values of Sun and McDonough [1989]. Note the relatively flat pattern of the youngest sample, 1039A-2H-5, $14 \mathrm{~cm}$.

Figure 8 . There is a general positive trend in the $\mathrm{Nb} / \mathrm{Zr}$ and $\mathrm{La} / \mathrm{Yb}$ proxies for relative enrichment in each elemental group, suggesting that these groups are partially coupled to one another during petrogenesis. Because these glasses are strongly evolved the trace element character reflects both the original melting process and the subsequent fractional crystallization so that the enrichment of the mantle wedge cannot be accurately assessed. The possible role of sediment subduction in petrogenesis can be considered by plotting the range of known compositions for trench sediments compiled by Kelly [2003] and analyzed from Deep Sea Drilling Project (DSDP) Site 495 by D. Cardace (Washington University, unpublished data, 2004). These show relatively low $\mathrm{La} / \mathrm{Yb}$ values and do not seem to be the cause of the greater enrichment seen in the tephras, at least not via simple assimilation. Instead the high $\mathrm{La} / \mathrm{Yb}$ values may be linked to the presence of garnet in the source and to extreme crystal fractionation processes (Figure 8).

\subsection{Tephra Provenance}

[23] The provenance of the Costa Rican tephras can be partially constrained by comparison with the trace element and REE patterns of possible source volcanoes on land. Unlike the major elements the trace element characteristics point strongly toward a link with the Costa Rican or possibly the Guatemalan section of the arc. Although Panamanian lavas show a reasonable match for many elements on the spider diagram they are more depleted in $\mathrm{La}, \mathrm{Ce}, \mathrm{Nd}$ and $\mathrm{Sm}$ compared to the tephra [Defant et al., 1991a, 1991b]. Recent lavas from Panama also tend to be calc-alkaline in character, while the tephra are dominantly tholeiitic (Figure 4a). In contrast Costa Rican and Guatemalan lavas show a closer match for these water immobile incompatible elements shown in Figure 6 and the overall slope of the REE curve

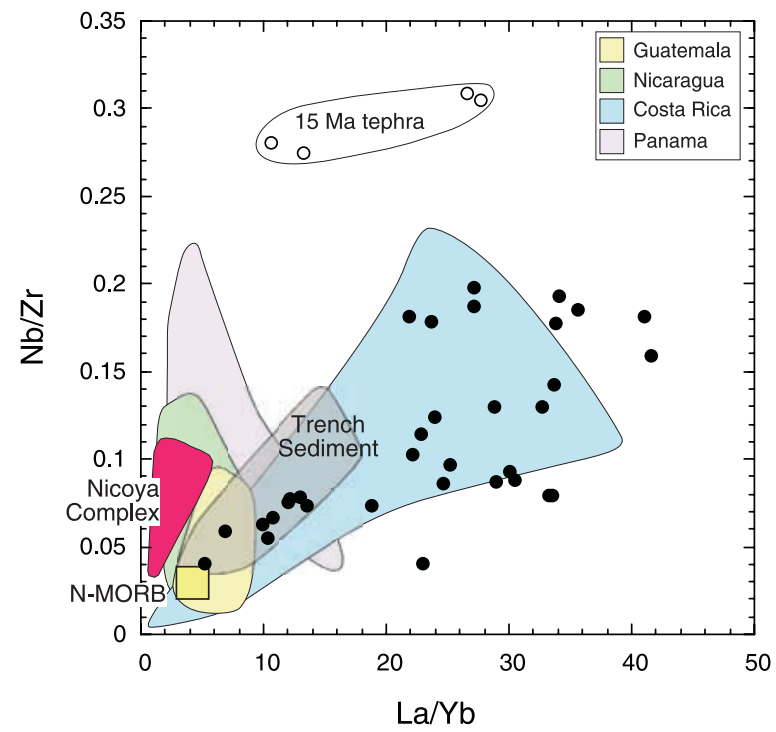

Figure 8. Plot of $\mathrm{La} / \mathrm{Yb}$ versus $\mathrm{Zr} / \mathrm{Nb}$ showing the lack of a clear trend between rare earth and high field strength elements and the general affinity of the tephra to known LREE-enriched Costan lavas. Central American arc fields are from GEOROC. Trench sediment data is from Kelly [2003]. 


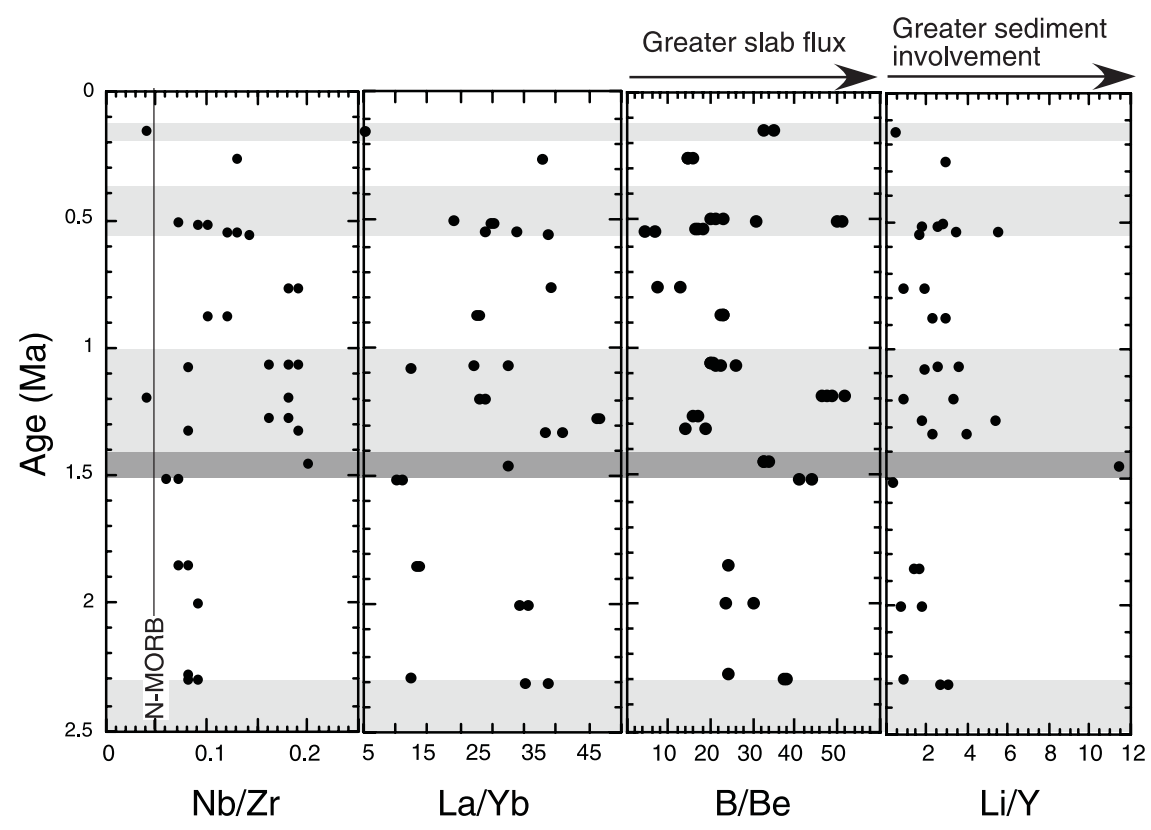

Figure 9. Diagram showing the evolution of trace element chemistry since $2.5 \mathrm{Ma}$. There is little coherency in terms of HFSE or REE development, but B/Be and Li/Y show periods of greater values (shown as gray shading) that suggest greater sediment recycling. Dark gray shading indicates a period of especially intense sediment recycling.

(Figure 7). The less steep REE curves form a minority that could also be related to Guatemalan centers. There is not a perfect match in trace element character between previously analyzed volcanic rocks from Costa Rica and the tephra studied here, which we interpret to be the result of higher fractional crystallization compared to the predominantly mafic lavas that were considered by earlier studies and the fact that we are comparing modern volcanic rocks and old tephra grains. Two older tephra layers analyzed, dated at 15.3 and $15.6 \mathrm{Ma}$, are interpreted to be derived from the Galapagos hot spot because the spider diagram shows no arc-related relative $\mathrm{Nb}$ depletion and, as described below, the trace element chemistry of these grains is quite discordant compared to the other analyses.

[24] The trace element character of the tephras shown in Figure 8 supports the evidence from spider and REE diagrams that indicate that most if not all the tephra cored offshore Nicoya are derived from the Costa Rican arc volcanoes of Central America, and thus provide the chance to examine how this limited section of arc has evolved since $2.5 \mathrm{Ma}$, without much complexity being introduced by along-strike variation. The high $\mathrm{La} / \mathrm{Yb}$ values in particular are distinctive of Costa Rican lavas, although those few lavas with lower $\mathrm{La} / \mathrm{Yb}$ values are also compatible with an origin in Guatemala, Panama or Nicaragua.

\subsection{Temporal Evolution}

[25] The magmatic development of the Costa Rican Arc can be tracked by plotting a selection of trace element proxies against age since $2.5 \mathrm{Ma}$. Figure 9 shows that there is no coherent trend in $\mathrm{Nb} / \mathrm{Zr}$ or $\mathrm{La} / \mathrm{Yb}$ that could be linked to a gradual evolution of the mantle wedge source or in the degree of melting and fractional crystallization. We also plot two proxies for slab flux, $\mathrm{Li} / \mathrm{Y}$, and $\mathrm{B} / \mathrm{Be}$. Each ratio represents an element that is enriched in the sediment or altered oceanic crust relative to the mantle wedge ( $\mathrm{B}$ and $\mathrm{Li}$ ) and another that is not ( $\mathrm{Be}$ and $\mathrm{Y}$ ). $\mathrm{B} / \mathrm{Be}$ is especially useful because the two elements have similar compatibility in igneous phases and consequently the ratio is not disturbed by fractional crystallization. Be is less fluid mobile than boron and is thus subducted to deeper levels, behaving much like a LREE [Tatsumi and Isoyama, 1988]. Although partition coefficients of $\mathrm{B}$ and $\mathrm{Be}$ can differ by two orders of magnitude under certain conditions [Chaussidon and Libourel, 1993], the correlation of $\mathrm{B} / \mathrm{Be}$ with other ratios indicative of slab-derived fluids demonstrates that these elements have very similar mineral-melt partition coefficients in most subduc- 

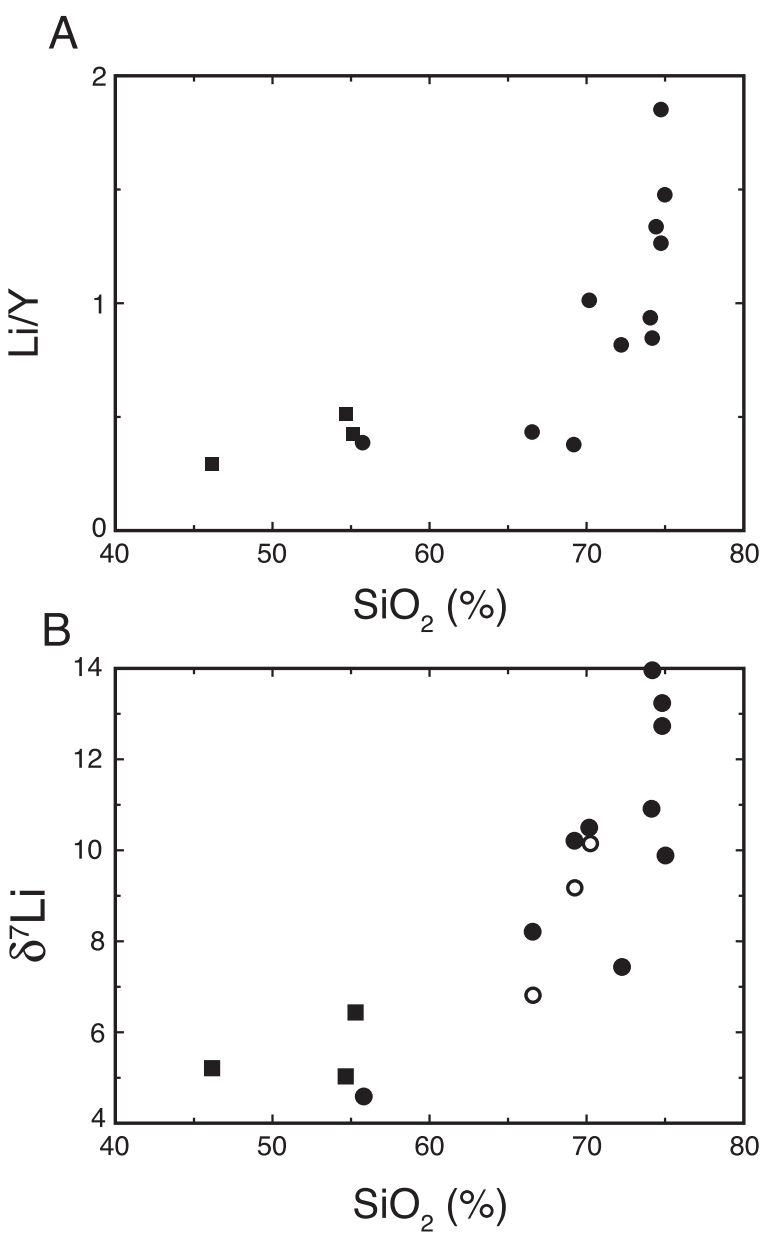

Figure 10. (a) Plot showing the relationship between $\mathrm{Li} / \mathrm{Y}$ and $\mathrm{SiO}_{2}$ and the effect that fractional crystallization has on relative $\mathrm{Li}$ enrichment. Solid dots represent tephra, while squares represent Costa Rican arc volcanoes. (b) Plot showing the relationship between $\delta^{7} \mathrm{Li}$ values and $\mathrm{SiO}_{2}$, demonstrating that isotopic character is also strongly affected by fractional crystallization. Open circles indicate acid washed tephra. Arc data are from Chan et al. [1999, 2002a].

tion zone environments [Ryan, 1989; Ryan and Langmuir, 1993]. Partial melting and fractional crystallization processes do not therefore significantly fractionate $\mathrm{B}$ from $\mathrm{Be}$, and variations in the $\mathrm{B} / \mathrm{Be}$ ratio in arc lavas are controlled primarily by differences in the slab input to the mantle sources of the lavas.

[26] Most arc lavas have significantly higher $\mathrm{B} / \mathrm{Be}$ ratios than mid-ocean ridge and oceanic island basalts, because boron is added to the source of the arc lavas by fluids derived from the subducting slab. The $\mathrm{B} / \mathrm{Be}$ ratio is thus a useful indicator of the amount of slab-derived boron in arc lavas [Morris et al., 1990; Edwards et al., 1993; Gill et al., 1993; Hochstaedter et al., 1996; Clift et al., 2003]. Correlations of the $\mathrm{B} / \mathrm{Be}$ ratio with ${ }^{10} \mathrm{Be} /{ }^{9} \mathrm{Be}$ in some arc lavas [Morris et al., 1990; Leeman et al., 1994] suggest that boron is derived at least in part from subducted sediment, and is rapidly transferred from the subducting slab to the surface in lavas (within about five half-lives of ${ }^{10} \mathrm{Be}$, or 7.5 m.y.). However, boron isotope studies show that the dehydration of the altered oceanic crust is typically the source of the bulk of the boron in arcs [e.g., Clift et al., 2003], consistent with oxygen isotopes that source most of the fluid in the serpentinized mantle lithosphere [Grove et al., 2002].

[27] While $\mathrm{B} / \mathrm{Be}$ does not show a coherent temporal evolution, it is noteworthy that the highest values are found in the periods $\sim 2.3,1.5-1.0$, $0.55-0.4$ and $\sim 0.15 \mathrm{Ma}$. Li/Y shows some of the same patterns as $\mathrm{B} / \mathrm{Be}$, but is clearly not well correlated. Li/Y has much less scatter than $\mathrm{B} / \mathrm{Be}$ and a clear maximum value at $1.45 \mathrm{Ma}$. Johnson and Plank [1999] showed that at $650^{\circ} \mathrm{C}$ (below melting temperature), $\mathrm{Li}$ is mobilized from the sediments to dehydration fluids and unlike Th and $\mathrm{Be}$, the partition coefficient (D) of $\mathrm{Li}$ does not change much after the temperature exceeds the solidus. Hydrothermal experiments also showed that $\mathrm{Li}$ is readily mobilized from sediments and altered basalts into aqueous fluids [Chan et al., 1994; Seyfried et al., 1998], but may also reflect melting and recycling of subducted sediment [Johnson and Plank, 1999]. In Central American arc lavas, Li has been closely correlated with fluid mobile elements, so that subducted Li may be carried to the mantle wedge via altered slab-derived fluids [Chan et al., 1999; 2002a].

[28] Whether transported by dehydration or by melting Li/Y may be a proxy for sediment involvement in arc petrogenesis. $\mathrm{Y}$ is relatively fluid immobile and its partitioning behavior during fractional crystallization closely resembles that of $\mathrm{Li}$ [Ryan and Langmuir, 1987]. Li is therefore normalized to $\mathrm{Y}$ to correct for the effect of fractional crystallization. However, Li/Y also increases sharply with $\mathrm{SiO}_{2}$ (Figure 10a). The observed trend suggests that $\mathrm{Li}$ is relatively enhanced to the magma during fractional crystallization especially when the melt composition reaches the rhyolitic range. This is supported by diffusion studies of Lesher [1986] who found changing partition behaviors of $\mathrm{Li}$ and $\mathrm{Y}$ in rhyolite. As fractional crystallization proceeds, $\mathrm{Li}$ could be incorporated into the magmas as a result of crustal or sediment 


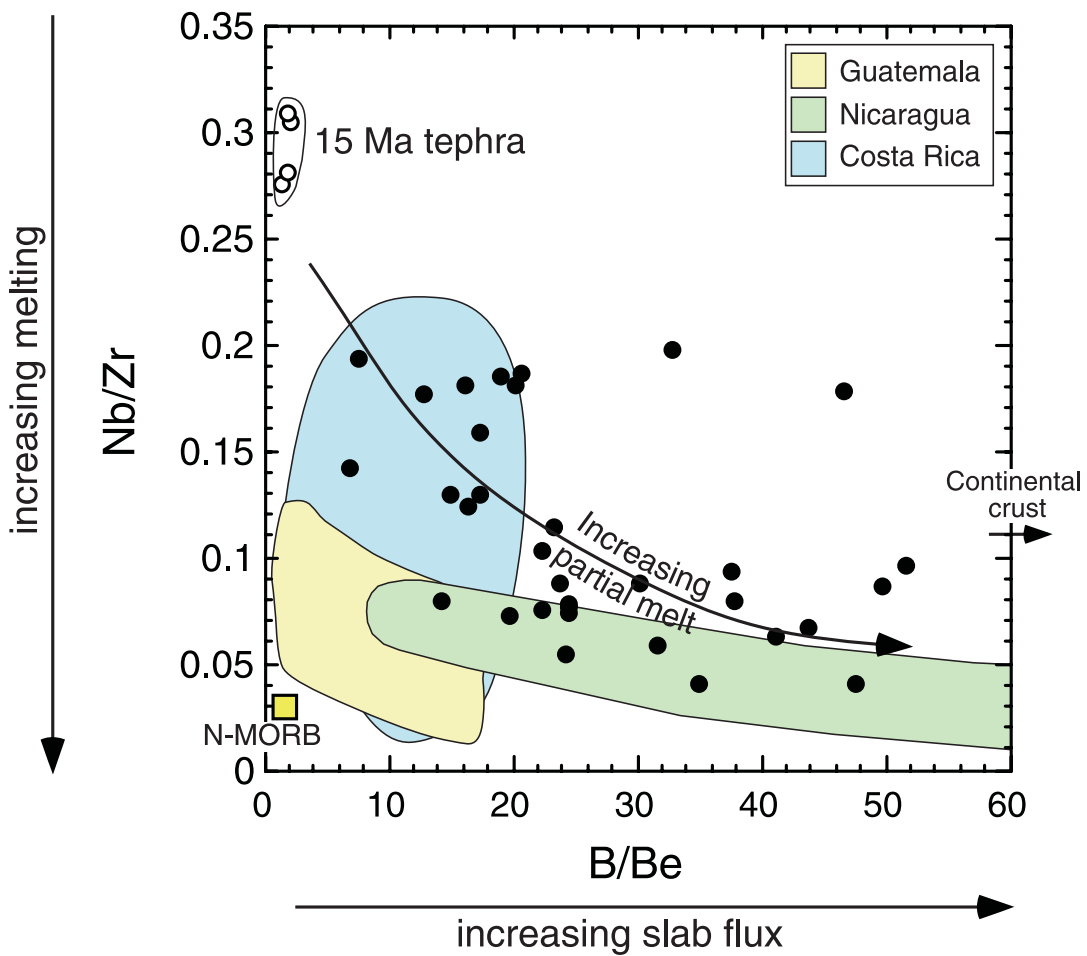

Figure 11. Plot showing the variation in HSFE enrichment versus B/Be for the Costa Rican forearc tephras, showing that they have scattered to much greater $\mathrm{B} / \mathrm{Be}$ values than now seen in Costa Rica, though similar to those recorded in Nicaragua arc volcanoes. There is a roughly defined negative correlation between $\mathrm{Nb} / \mathrm{Zr}$ and $\mathrm{B} / \mathrm{Be}$.

assimilation. Thus the increase of $\mathrm{Li} / \mathrm{Y}$ with increasing $\mathrm{SiO}_{2}$ is believed to be a combined effect of fractional crystallization and assimilation. The very high $\mathrm{Li} / \mathrm{Y}$ value dated at $1.45 \mathrm{Ma}$ points to a peak in $\mathrm{Li}$ input from the slab at that time. The $\mathrm{Li} / \mathrm{Y}$ and $\mathrm{B} / \mathrm{Be}$ data show that slab flux and sediment subduction to the roots of the magmatic arc were enhanced over short, yet regular periods.

\subsection{Controls on Melt Production}

[29] HFSE and REEs appear to be coupled at a first order level, suggesting that the composition of the mantle source and/or the degree of partial melting is the principal control on their concentrations in the tephra. Melting in arcs is a controversial topic, although there is some consensus that flux of fluid from the subducting plate is a primary control [e.g., Tatsumi et al., 1983]. Using B/Be as a proxy for the volume of slab flux we assess the links between HFSE depletion and flux (Figure 11). The data do not show a strong trend, yet there is a broad negative correlation between $\mathrm{Nb} / \mathrm{Zr}$ and $\mathrm{B} / \mathrm{Be}$, as might be expected if greater fluid flux drives more melting. The large scatter suggests that other processes are also influencing HFSE enrichment;

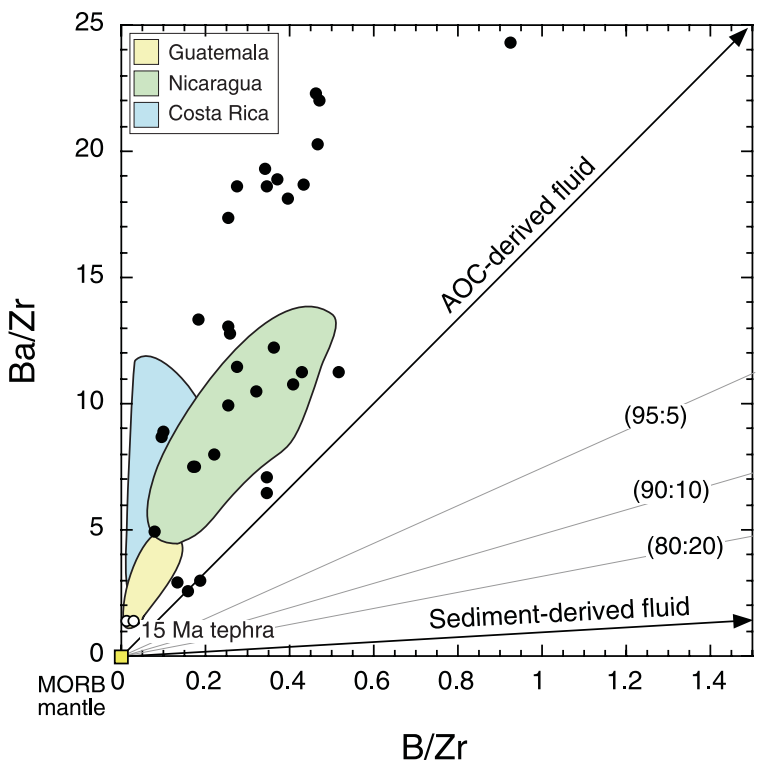

Figure 12. Plot of Costa Rican tephra on a $\mathrm{Ba} / \mathrm{Zr}$ versus B/Zr plot [after Sano et al., 2001]. Despite the scatter it is clear that the Costa Rican glass compositions are compatible with melt production from a fluid dominated by the altered oceanic crust and overlap with lavas measured from both Nicaragua and Costa Rica. 
A

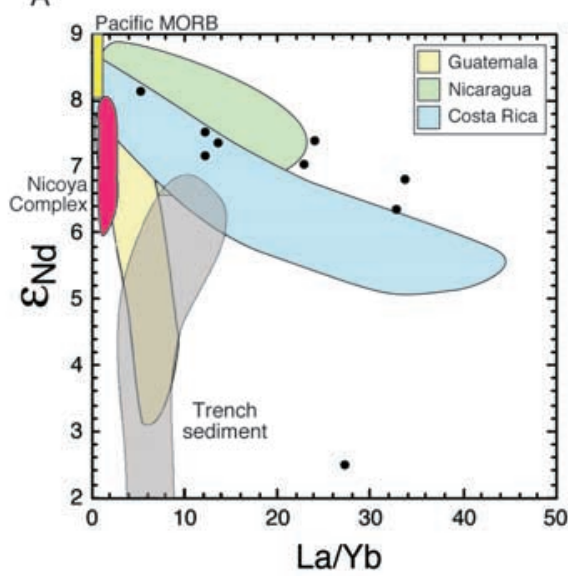

$\mathrm{B}$

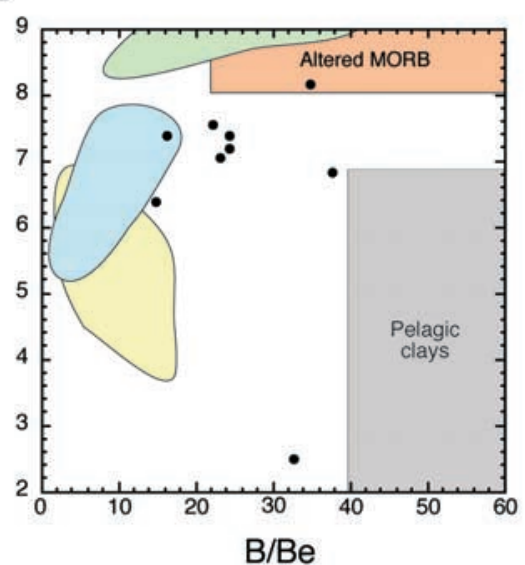

Figure 13. Diagrams showing the relationship of $\mathrm{Nd}$ isotopes in the Costa Rica tephra with (a) LREE element enriched, as tracked by $\mathrm{La} / \mathrm{Yb}$, (b) slab flux as tracked by B/Be. Central American arc fields are from GEOROC. Trench sediment data are from Kelly [2003] and Morris et al. [1990].

either variations in the mantle source or remelting of subducted sediment.

[30] The origin of the boron carried by aqueous fluid to the arc can be assessed using a model developed by Sano et al. [2001] for relatively primitive lavas from the Japan-Honshu Arc (Figure 12). This model suggests that the altered oceanic crust is dominant as a source of boron to the arc. Although we are plotting evolved glasses it is noteworthy that the more primitive rocks in the GEOROC database also show this general trend. The model is clearly not completely appropriate because the points plot above the 100\% altered oceanic crust line, but this does offer a strong indication of where most of the fluid is being derived from. This conclusion makes geodynamic sense given the small thickness of sediment on the subducting plate, compared to the amount of water stored as alteration products in the much thicker altered oceanic crust and serpentinized mantle lithosphere [e.g., Grove et al., 2002].

\section{Isotope Chemistry}

[31] The influence of sediment subduction and fluid flux on melting can be more rigorously assessed using the isotopic data collected from the same tephra grains. Isotopic methods are useful because they are generally not susceptible to change due to partial melting or crystal fractionation [Tomascak et al., 1999].

\subsection{Tracing Sediment Flux}

[32] The Nd isotope system is considered to be particularly sensitive to input from subducted sediment because $\mathrm{Nd}$ is a water-immobile element with large differences seen between mantle and continental compositions, allowing easy resolution of mixing relations. Figure 13a shows the relationship between LREE enrichment and continental recycling, probably in the form of trench sediments. There is a broad correlation showing that those tephra samples with lowest $\varepsilon_{\mathrm{Nd}}$ values have some of the highest LREE enrichment, consistent with the idea that sediment recycling can exercise a strong control on the arc REE chemistry. One sample dated at $1.45 \mathrm{Ma}$ has an extreme $\varepsilon_{\mathrm{Nd}}$ value, falling off the general trend defined by the other samples, and implying very high degrees of continental recycling. Comparison with known values of trench sediments [Kelly, 2003] shows that this is not a simple mixing relationship because the LREE enrichment of the glasses is higher than trench sediments. The Nicoya Complex, which is presumed to be representative of the crust into which the arc was emplaced, cannot be causing the $\mathrm{Nd}$ isotope excursion because this is very positive in $\varepsilon_{\mathrm{Nd}}$ (Figure 13). Instead it is likely that extreme crystal fractionation is the cause of the REE mismatch and that continental sediment subduction can explain the low values of $\varepsilon_{\mathrm{Nd}}$ seen in that 
sample. It is noteworthy that the lowest $\varepsilon_{\mathrm{Nd}}$ value is comparable to $\varepsilon_{\mathrm{Nd}}$ values seen in the shallow buried trench sediments measured by Kelly [2003]. The sediments are not erosional products of the Nicoya Complex or its equivalents, but must be derived along strike from older continental crust to the northwest.

[33] A simple estimate of sediment recycling can be made if we assume three end-member mixing between a mantle source of $+8.5 \varepsilon_{\mathrm{Nd}}$ value, a forearc basement of Nicoya Complex composition $\left(\varepsilon_{\mathrm{Nd}}=+7.1\right)$ and a sediment with $\varepsilon_{\mathrm{Nd}}=-4.3$, which is the average of the two values measured by D. Cardace (unpublished data) from the lower carbonate part of the sedimentary section at DSDP Site 495. A combination of $\mathrm{Li}$ and $\mathrm{Nd}$ isotopes suggest that it is lower part of the subducting sedimentary section that is the dominant contributor to the arc volcanism (Figure 15). Concentrations of $\mathrm{Nd}$ in the lower sediment, altered oceanic crust and mantle melt are 5-10 ppm [Sun and McDonough, 1989]. Using a simple mixing calculation we estimate that most of the tephra glasses represent $<17 \%$ sediment recycling, many $<10 \%$, and with the most recent (1039A-2H-5, $14 \mathrm{~cm})$ at only 5\%. In contrast Sample 1039B-11H-7, $38 \mathrm{~cm}$ is noteworthy in representing $41 \%$ sediment recycling. Whether these percentages have any true meaning is unclear because Class et al. [2000] estimated that melt from sediment can have $183 \mathrm{ppm}$ or $13 \mathrm{ppm} \mathrm{Nd} \mathrm{depending} \mathrm{on} \mathrm{sediment/}$ melt partition coefficient that can vary from 0.06 to 1.53. The precise numbers are also dependent on our choice of end-member composition, which is not tightly defined in this case. It seems unlikely that the proportion of sediment recycling was as high as $41 \%$ in Sample 1039B-11H-7, $38 \mathrm{~cm}$ because such a level of recycling might be expected to have affected the major and trace element character, which is not anomalous in this case. Regardless of whether the calculated percentages are accurate or not it is clear that sediment recycling peaked at the time of Sample 1039B$11 \mathrm{H}-7,38 \mathrm{~cm}, \sim 1.45 \mathrm{Ma}$.

[34] Similarly we can estimate the petrogenetic contribution from a forearc crustal source, presumed to be close to the Nicoya Complex in $\mathrm{Nd}$ composition and to altered oceanic crust in terms of Li. Like the sediment contribution it is not clear that these numbers are strictly accurate but do show some of the variability in terms of crustal assimilation since 2.5 Ma. Our mixing calculations show that the most recent sample has the lowest contri- bution in this component $(8 \%)$, and that there has been significant variability that does not coincide with the sedimentary influence. The strongest crustal influence is to be found in Sample 1039B-10H-1, $38 \mathrm{~cm}$, when the sedimentary contribution is at a minimum.

[35] Plotting $\mathrm{B} / \mathrm{Be}$ against $\varepsilon_{\mathrm{Nd}}$ values allows the relationship between fluid and continental recycling to be assessed (Figure 13b). Perhaps not surprisingly there is no coherent pattern to the Costa Rican tephra data, because boron largely reflects dehydration of the altered oceanic crust, while $\mathrm{Nd}$ isotopes are more controlled by melting of subducted sedimentary rocks. While the degree of sediment recycling does appear to vary within set limits one sample in particular stands out as having very high sediment influence in petrogenesis.

\subsection{Insights From Li Isotopes}

[36] Comparison of $\delta^{7} \mathrm{Li}$ of acid-washed and unwashed tephra grains provides some insight on the degree of alteration. Li isotope composition of volcanic glass is highly susceptible to alteration by seawater and sediment pore fluids that would result in enrichment of ${ }^{7} \mathrm{Li}$ in the altered glass. Of the three pairs of samples studied, $\delta^{7} \mathrm{Li}$ of the acid washed samples are always higher than that of the unwashed counterpart. The differences range from 0.35 to $1.4 \%$, which are not significantly greater than the analytical error, but the slightly higher value could reflect a small degree of alteration.

[37] Figure 14 shows the relationship between $\delta^{7} \mathrm{Li}$ and $\mathrm{Y} / \mathrm{Li}$ values in bulk tephra samples, as well as lavas from recent Costa Rican volcanoes (Arenal, Platanar and Irazu) [Chan et al., 1999, 2002a]. The tephra shards are highly enriched in Li and many have higher $\delta^{7} \mathrm{Li}$ values than the lavas of modern Costa Rica. The tephra display a general inverse relationship between $\delta^{7} \mathrm{Li}$ and $\mathrm{Y} / \mathrm{Li}$, indicating addition of isotopically heavy $\mathrm{Li}$ to the magma.

[38] To understand the extent of sediment recycling and the contribution of other sources we compare the $\mathrm{Li}$ isotopic composition with $\varepsilon_{\mathrm{Nd}}$ (Figure 15). Chan and Kastner [2000] reported the $\delta^{7} \mathrm{Li}$ values of sediments at ODP Site 1039 at 10.4-12.7\%o, although these values have since been revised (L. H. Chan, unpublished data). Clay-rich, trench sediments from the upper part of that section have $\delta^{7} \mathrm{Li}$ of 2-4\%, while deeper carbonate sediments have $\delta^{7} \mathrm{Li}$ of $6-12 \%$ (Figure 15). This plot shows that the sediments from the shallow part of the stratig- 


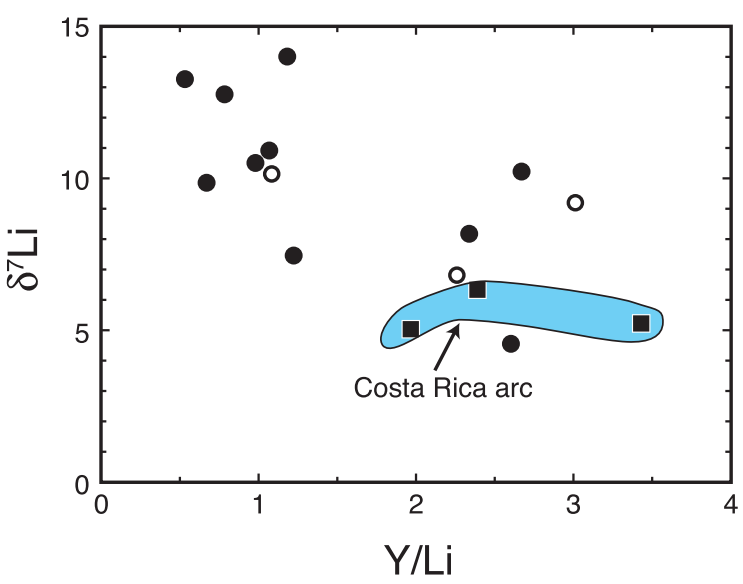

Figure 14. Plot showing the relationship between $\delta^{7} \mathrm{Li}$ and $\mathrm{Y} / \mathrm{Li}$ in bulk tephra, as well as terrestrial lavas of the Costa Rican arc. Symbols and data sources are as in Figure 10.

raphy do not make good end-member mixing components, with more influence on petrogenesis shown by the sediments deeper in the section. However, because Li is not abundant in carbonate sediments, our $\mathrm{Li}$ data do not present strong evidence for sediment recycling through the arc volcanic roots. Many of the grains appear to trend toward an uncharacterized end-member with relatively positive $\varepsilon_{\mathrm{Nd}}$ value and high $\delta^{7} \mathrm{Li}$ values. This might reflect the contribution from altered oceanic crust and possibly the influence of a third source, such as tectonically eroded forearc basement. Oceanic crust altered at low temperatures is enriched in $\delta^{7} \mathrm{Li}$ (up to $20 \%$ o [Chan et al., 1992, 2002b]) due to incorporation of seawater $\mathrm{Li}$. It is possible that dehydration fluids from altered oceanic crust contribute to the heavy isotopic signature of those shards that also have positive $\varepsilon_{\mathrm{Nd}}$ values.

[39] Evidence for large-scale tectonic erosion of this margin [Vannucchi et al., 2001, 2003] raises the possibility that the forearc basement itself might be a candidate for this component. The $\varepsilon_{\mathrm{Nd}}$ values of the Nicoya Complex, which is presumed to underlie the forearc are consistent with this model. Although the $\delta^{7} \mathrm{Li}$ values of the forearc basement are unknown, they could be similar to those of old, altered oceanic crust. Like $\mathrm{Li} / \mathrm{Y}, \delta^{7} \mathrm{Li}$ increases with $\mathrm{SiO}_{2}$ (Figure $10 \mathrm{~b}$ ), suggesting assimilation of crustal material during prolonged fractional crystallization. The basement under the Costa Rican segment of the Central American Arc consists of oceanic and arc crust ranging in age from Cretaceous to Neogene [Leeman and Carr, 1995]. We therefore postulate that incorporation of material from old altered crust in the ascending melt results in an increase in $\delta^{7} \mathrm{Li}$ in the glasses.

[40] Tomascak et al. [2000] reported that a group of calc-alkaline lavas from Panama that crystallized between 20 and $5 \mathrm{Ma}$ have $\delta^{7} \mathrm{Li}$ as high as $11.2 \%$, whereas younger lavas have lower MORB-like $\delta^{7} \mathrm{Li}$ values of $2-5 \%$. High $\delta^{7} \mathrm{Li}$ relative to MORB was interpreted as derived from the slab component. Isotopically heavy $\mathrm{Li}$ from the slab fluids may have been retained in the subarc mantle and later extracted for melt production in a thermally mature mantle. We do not consider Panama to be the source of the tephra with high $\delta^{7} \mathrm{Li}$ values because the major and trace element data discussed above argue against this province. All the Panama samples analyzed are calc-alkaline whereas some tephra samples in this study are tholeiitic (Figure 4a). The spidergram (Figure 6) shows that the Panama samples are relatively low in $\mathrm{La}, \mathrm{Ce}$,

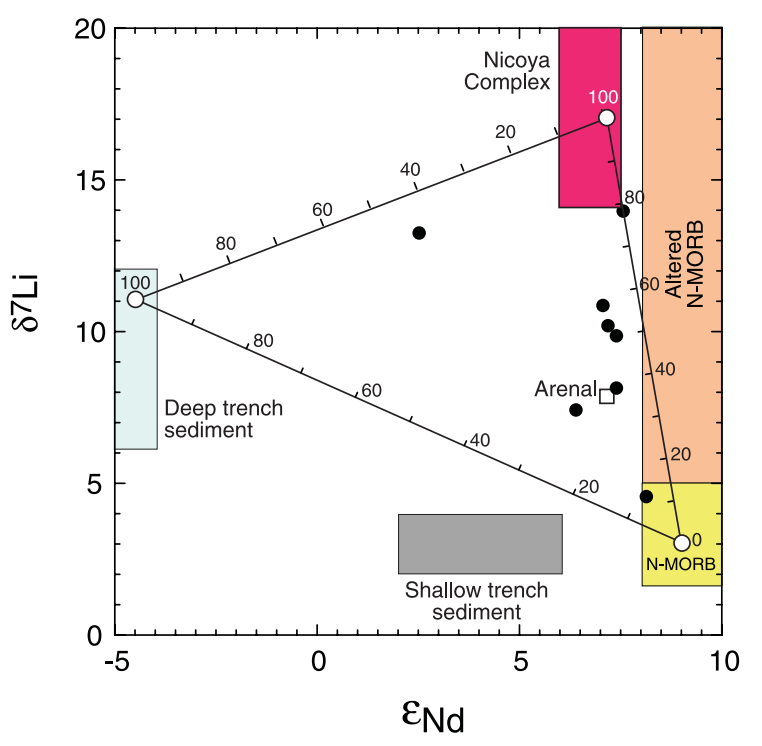

Figure 15. Plot of $\varepsilon_{\mathrm{Nd}}$ and $\delta^{7} \mathrm{Li}$ shows that while the majority of tephra glasses could be explained by a petrogenesis mixing recycled MORB crust and subducted sediments, an additional, likely forearc component is required that may be comparable to the Nicoya Complex exposed onshore. Nd isotope data of sediments are from Kelly [2003] and unpublished data of D. Cardace (Washington University). Li isotope data of sediments are a revision of published data of Chan and Kastner [2000]. N-MORB and altered N-MORB fields are from Chan et al. [1992, 2002b]. Circles represent end-member compositions for mixing calculations. 


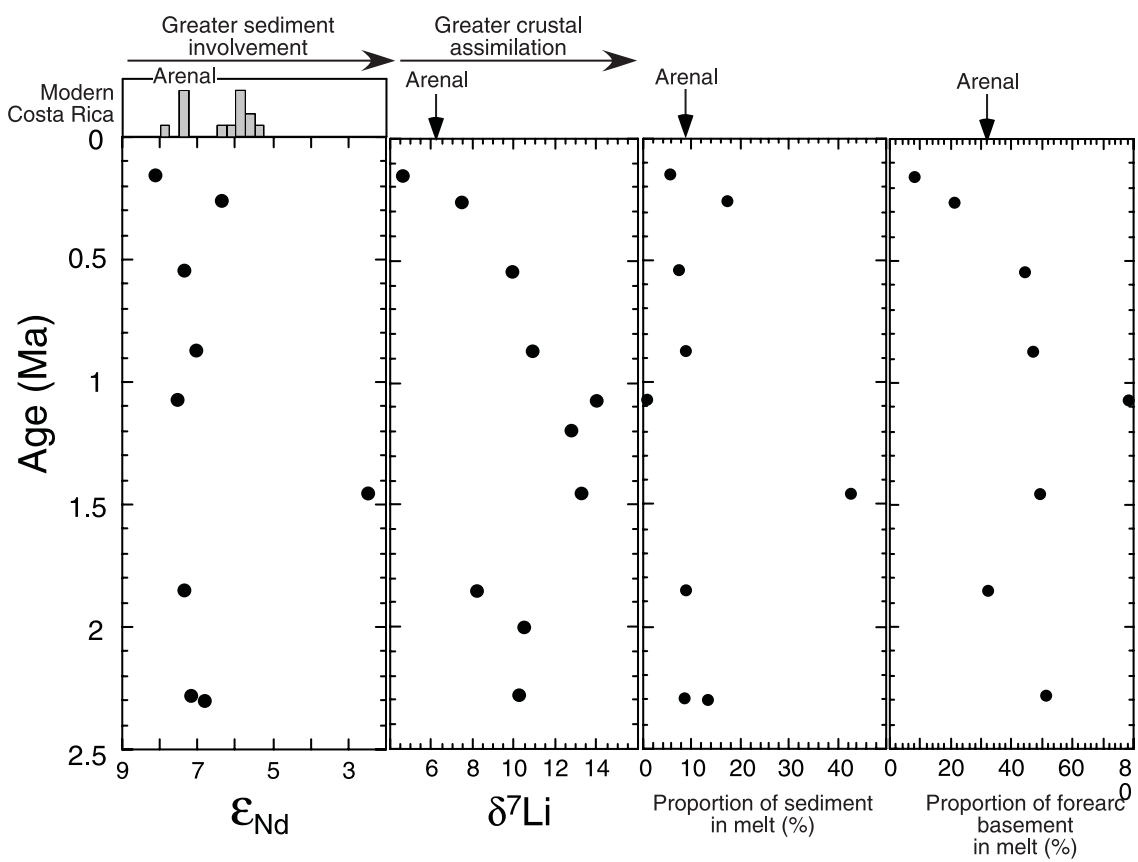

Figure 16. Diagram showing the evolving Li, Nd, and B isotopic composition of Costa Rican tephras since $2.5 \mathrm{Ma}$. Histogram of $\varepsilon_{\mathrm{Nd}}$ values for modern Costa Rica is from GEOROC. Modern $\delta^{7} \mathrm{Li}$ value for Arenal volcano is from Chan et al. [1999]; Nd data are from Feigenson et al. [2004]. Sediment proportion of petrogenesis is calculated from end-member mixing model based on $\mathrm{Nd}$ isotopes.

$\mathrm{Nd}$, and Sm. Furthermore, because of the apparent age differences, we cannot establish a firm genetic link between our tephra samples and the 20 to 5 Ma Panamanian lavas of Tomascak et al. [2000]. Younger lavas from Panama do not show such high $\delta^{7} \mathrm{Li}$ values. However, it remains possible that slab-derived $\mathrm{Li}$ that was stored in the subarc mantle may contribute to the heavy $\delta^{7} \mathrm{Li}$ signature of the glasses. This explanation could also account for the MORB-like Nd isotope compositions.

\subsection{Temporal Isotope Evolution}

[41] Figure 16 shows how the Costa Rican Arc has evolved through time since $2.5 \mathrm{Ma}$ in terms of $\mathrm{Nd}$ and $\mathrm{Li}$ isotopes, each of which is sensitive to different aspects of the flux from the sediments, oceanic slab and possibly the forearc basement. Both $\delta^{7} \mathrm{Li}$ and $\varepsilon_{\mathrm{Nd}}$ show extreme values at $1.45 \mathrm{Ma}$, although subsequently their histories are quite different. Low $\varepsilon_{\mathrm{Nd}}$ indicates high degrees of sediment subduction at $1.45 \mathrm{Ma}$, consistent with the synchronous high $\mathrm{Li} / \mathrm{Y}$ and $\mathrm{B} / \mathrm{La}$ values. In contrast, high $\delta^{7} \mathrm{Li}$ may point to increased crustal assimilation at and for some time after 1.45 Ma. What is clear is that the Costa Rican Arc has experienced large scale, long-term changes in isotope character and that the modern isotope com- position of the adjacent volcanoes seems to represent a relatively low degree of sediment recycling compared to what we now infer for the geologic past.

\section{Discussion}

[42] The tephra geochemistry presented in the study allows the temporal evolution of the Costa Rican section of the Central American magmatic arc to be reconstructed in detail back to $2.5 \mathrm{Ma}$ for the first time. Before $2.5 \mathrm{Ma}$ the only tephra recognized on the subducting plate were of Galapagos provenance, deposited on the oceanic crust when it was located much closer to that hot spot. The Central American Arc was active prior to 2.5 Ma, however the drilled sedimentary section now in the trench was too far offshore prior to that time to accumulate a preservable record of explosive magmatism. Tephra either did not reach the drill site in its distal position prior to that time, or were thin and reworked by bioturbation. The forearc region offshore Nicoya Peninsula does not provide a good record of volcanism because there are no subbasins where sediment might pond. Instead the slope is characterized by mass wasting and debris flow activity, reworking tephra that fall in this setting. 
[43] Trace element data are consistent in showing that most of the tephra deposited since $2.5 \mathrm{Ma}$ were derived from the Costa Rican area, though a few might have been derived from Nicaragua, just to the north. This pattern is in line with modern depositional patterns governed by wind directions. Major element compositions show moderate longterm evolution due to changing degrees of fractional crystallization, though it is not clear what is governing that shift. Most striking is the presence of a mafic tephra at $150 \mathrm{ka}$ following a consistently siliceous record prior to that time. The tectonic setting of the region is not believed to have changed much since $2.5 \mathrm{Ma}$ and changes in major element chemistry may thus only reflect local changes in magmatic plumbing and magma storage. Alternatively, assuming mafic eruptions are less explosive than siliceous ones, it is possible that it is only in the most recent geologic past that the section now in the trench has come in range of this type of deposit.

[44] Because most of the tephra are very evolved petrogenesis is not unambiguously interpretable from these materials. Nonetheless, the HFSEs and REEs do seem to be coupled to each other and are related to the degree of continental sediment recycling in the arc, as well as the degree of fractionation. This result is in accord with the general findings of Patino et al. [2000] based on more mafic recent, terrestrial lavas. Analysis of boron concentrations indicates that much of the fluid input into the magmatic arc is derived from the altered oceanic crust, although the sediment column must contribute to a lesser extent. Although $\mathrm{Pb}$ isotope data has been used to argue against large-scale sediment involvement in petrogenesis in Central America [e.g., Feigenson et al., 1993] recent data has shown that the trench sediments are very unradiogenic in $\mathrm{Pb}$ and that large scale recycling of the type we propose is possible [Feigenson et al., 2004].

[45] The trace element character of the arc shows some temporal changes of note, most particularly in $\mathrm{Li} / \mathrm{Y}$ and $\mathrm{B} / \mathrm{Be}$, that point to variations in the degree of slab flux, sediment recycling, and crustal assimilation. Four periods are identified during which slab flux appears to have been stronger than the present-day, $2.5-2.3,1.5-1.0,0.55-0.4$ and $\sim 0.15 \mathrm{Ma}$. Using the $\mathrm{Nd}$ isotopic data, we pinpoint the time around $1.45 \mathrm{Ma}$ as being a period of especially strong sediment subduction, followed by a period of enhanced crustal assimilation and recycling shown by the $\mathrm{Li}$ isotopes. This is an important observation because studies of the modern arc volcanic rocks [e.g., Morris et al., 1990; Carr et al., 2003] indicate that little sediment is now being recycled in the Costa Rica region, an observation that is hard to reconcile with geologic data for rapid tectonic erosion and thus complete subduction of the sediment column at least since the Miocene [Vannucchi et al., 2001]. Our tephra record now suggests that the present-day may be a period in which little sediment is subducted as deep as the magmatic roots of the arc, due to offscraping or underplating on to the forearc. However, such periods of low recycling are interspersed by periods in which larger amounts of sediment were subducted. During these periods not only would the sedimentary cover be subducted but also any temporary accretionary prism would be removed and subducted. In practice this allows the shortterm geochemical evidence for sediment accretion to be reconciled with the geological evidence for long-term subduction erosion.

[46] One possible scenario to explain the isotope patterns observed would involve collision of a seamount with the forearc just before $1.45 \mathrm{Ma}$ that would have tectonically eroded any accretionary body, driving a brief peak in the degree of sediment subduction. However, tectonic disruption by the seamount could then lead to a longer period of faster tectonic erosion of the forearc, lasting $\sim 0.5$ m.y., as the margin regained an equilibrium geometry. Subsequently tectonic erosion, geometric readjustment of the forearc and crustal recycling would decrease to the present levels, as traced by $\delta^{7} \mathrm{Li}$.

\section{Conclusions}

[47] Central America is a classic area of study for those attempting understanding of the tectonics of subduction and the origin of melts in magmatic arcs. In the past there has been a problem reconciling sedimentary and tectonic evidence that indicates long-term trench retreat and tectonic erosion with chemical data that indicated little sedimentary influence on petrogenesis, presumably due to accretion of sediments from the oceanic plate to the toe or underside of the forearc. Analysis of single glass shards from tephra layers recovered mostly from the subducting sediment section now allows the history of magmatism to be reconstructed. A combination of major and trace elements, together with $\mathrm{Nd}$ isotopes now shows that sediment subduction and remelting was a key control on sub- 
duction petrogenesis in the Costa Rica area since $2.5 \mathrm{Ma}$. Boron is however largely decoupled and is instead controlled by dewatering from the subducting altered oceanic crust with lesser influence from the subducted sediments. Li isotopes are also decoupled from the sediment recycling process and seem to reflect crustal assimilation, possibly related in part to the tectonic erosion of the forearc, and some degree of slab contribution. Because the historical magmatism since 2.5 Ma from Costa Rica features several periods of higher sediment influence, most strongly at $1.45 \mathrm{Ma}$, we conclude that the present low degree of recycling is not typical of the arc over long periods of geologic time and thus that there is no major discrepancy between the geochemistry and the inferred longterm loss of crust from this margin.

\section{Acknowledgments}

[48] We thank the crew of JOIDES Resolution for their professionalism in helping to collect the core material studies here. Financial support for the analytical work was gratefully received from JOI-USSAC. The lithium isotope work was supported in part by National Science Foundation grant OCE990554 to L.H.C. The paper was improved thanks to helpful reviews from Mary Reid, Jeff Ryan, and Paul Tomascak.

\section{References}

Barckhausen, U., C. R. Ranero, R. von Huene, S. C. Cande, and H. A. Roeser (2001), Revised tectonic boundaries in the Cocos plate off Costa Rica: Implications for the segmentation of the convergent margin and for plate tectonic models, J. Geophys. Res., 106, 19,207-19,220.

Burnham, C. W., and R. H. Jahns (1962), A method of determining the solubility of water in silicate melts, Am. J. Sci., 260, $721-745$.

Carr, M. J. (1984), Symmetrical and segmented variation of physical and geochemical characteristics of the Central America volcanic front, J. Volcanol. Geotherm. Res., 20, 231-252.

Carr, M. J., M. D. Feigenson, and E. A. Bennett (1990), Incompatible element and isotopic evidence for tectonic control of source mixing and melt extraction along the Central American arc, Contrib. Mineral. Petrol., 105, 369-380.

Carr, M. J., M. D. Feigenson, L. C. Patino, and J. A. Walker (2003), Volcanism and geochemistry in Central America: Progress and problems, in Inside the Subduction Factory, Geophys. Monogr. Ser., vol. 138, edited by J. Eiler, pp. 153-174, AGU, Washington, D. C.

Chan, L. H., and F. A. Frey (2003), Lithium isotope geochemistry of the Hawaiian plume: Results from the Hawaii Scientific Drilling Project and Koolau Volcano, Geochem. Geophys. Geosyst., 4(3), 8707, doi:10.1029/2002GC000365.

Chan, L.-H., and M. Kastner (2000), Lithium isotopic compositions of pore fluids and sediments in the Costa Rica subduction zone: Implications for fluid processes and sediment contribution to the arc volcanoes, Earth Planet. Sci. Lett., $183,275-290$.
Chan, L.-H., J. M. Edmond, G. Thompson, and K. Gillis (1992), Lithium isotopic composition of submarine basalts: Implications for the lithium cycle in the oceans, Earth Planet. Sci. Lett., 108, 151-160.

Chan, L.-H., J. M. Gieskes, C. F. You, and J. M. Edmond (1994), Lithium isotope geochemistry of sediments and hydrothermal fluids of the Guaymas Basin, Gulf of California, Geochim. Cosmochim. Acta, 58, 4443-4454.

Chan, L.-H., W. P. Leeman, and C. F. You (1999), Lithium isotopic composition of Central American Volcanic Arc lavas: Implications for modification of subarc mantle by slabderived fluids, Chem. Geol., 160, 255-280.

Chan, L. H., W. P. Leeman, and C.-F. You (2002a), Lithium isotopic composition of Central American volcanic arc lavas: Implications for modifications of subarc mantle by slab-derived fluids: Correction, Chem. Geol., 182, 293-300.

Chan, L. H., J. C. Alt, and D. A. H. Teagle (2002b), Lithium and lithium isotope profiles through the upper oceanic crust: A study of seawater-basalt exchange at ODP sites 504B and 896A, Earth Planet. Sci. Lett., 201, 187-201.

Chaussidon, M., and G. Libourel (1993), Boron partitioning in the upper mantle-An experimental and ion probe study, Geochim. Cosmochim. Acta, 57, 5053-5062.

Christeson, G. L., K. D. McIntosh, T. H. Shipley, E. R. Flueh, and H. Goedde (1999), Structure of the Costa Rica convergent margin, offshore Nicoya Peninsula, J. Geophys. Res., 104, 25,443-25,468.

Class, C., D. M. Miller, S. L. Goldstein, and C. H. Langmuir (2000), Distinguishing melt and fluid subduction components in Umnak Volcanics, Aleutian Arc, Geochem. Geophys. Geosyst., 1(6), doi:10.1029/1999GC000010.

Clift, P. D., and P. Z. Vroon (1996), Isotopic evolution of the Tonga Arc system during Lau Basin rifting: Evidence from the volcaniclastic record, J. Petrol., 37, 1153-1173.

Clift, P. D., G. D. Layne, Y. M. R. Najman, A. Kopf, N. Shimizu, and J. Hunt (2003), Temporal evolution of boron flux in the Honshu and Izu Arcs measured by ion microprobe from the forearc tephra record, J. Petrol., 44, 1211-1236.

Defant, M. J., L. F. Clark, R. H. Stewart, M. S. Drummond, J. Z. de Boer, R. C. Maury, H. Bellon, T. E. Jackson, and J. F. Restrepo (1991a), Andesite and dacite genesis via contrasting processes: The geology and geochemistry of El Valle Volcano, Panama, Contrib. Mineral. Petrol., 106, 309-324.

Defant, M. J., P. M. Richerson, J. Z. de Boer, R. H. Stewart, R. C. Maury, H. Bellon, M. S. Drummond, M. D. Feigenson, and T. E. Jackson (1991b), Dacite genesis via both slab melting and differentiation: Petrogenesis of La Yeguada volcanic complex, Panama, J. Petrol., 32, 1142-1301.

DePaolo, D. J., and G. J. Wasserburg (1976), Nd isotopic variations and petrogenetic models, Geophys. Res. Lett., 3, 249-252.

Edwards, C. M. H., J. D. Morris, and M. F. Thirlwall (1993), Separating mantle from slab signatures in arc lavas using B/ $\mathrm{Be}$ and radiogenic isotope systematics, Nature, 362, 530533.

Feigenson, M. D., M. J. Carr, and S. V. Maharaj (1993), Preliminary $\mathrm{Pb}$ isotope data for the Central American volcanic arc, Eos Trans. AGU, 74(43), Fall Meet. Suppl., 680.

Feigenson, M. D., M. J. Carr, S. V. Maharaj, S. Juliano, and L. L. Bolge (2004), Lead isotope composition of Central American volcanoes: Influence of the Galapagos plume, Geochem. Geophys. Geosyst., 5, Q06001, doi:10.1029/ 2003GC000621.

Flesch, G. D., A. R. Anderson, Jr., and H. J. Svec (1973), A secondary isotopic standard for lithium determinations, Int. J. Mass. Spectrom. Ion Phys., 12, 265-272. 
Gill, J. B., J. D. Morris, and R. W. Johnson (1993), Timescale for producing the geochemical signature of island arc magmas; U-Th-Po and Be-B systematics in Recent Papua New Guinea lavas, Geochim. Cosmochim. Acta, 57, 4269-4283.

Grove, T. L., S. W. Parman, S. A. Bowrig, R. C. Price, and M. B. Baker (2002), The role of an $\mathrm{H}_{2} \mathrm{O}$-rich fluid component in the generation of primitive basaltic andesites and andesites from the Mt. Shasta region, N California, Contrib. Mineral. Petrol., 142, 375-396.

Hamilton, P. J., R. K. O’Nions, D. Bridgwater, and A. Nutman (1983), Sm-Nd studies of Archaean metasediments and metavolcanics from West Greenland and their implications for the Earth's early history, Earth Planet. Sci. Lett., 62, 263272 .

Hauff, F., K. Hoernle, H. U. Schmincke, and R. Werner (1997), A mid Cretaceous origin for the Galapagos hotspot: Volcanological, petrological and geochemical evidence from Costa Rican oceanic crustal segments, Geol. Rundsch., 86, 141155.

Hochstaedter, A. G., J. G. Ryan, J. F. Luhr, and T. Hasenaka (1996), On B/Be ratios in the Mexican volcanic belt, Geochim. Cosmochim. Acta, 60, 613-628.

Johnson, M. C., and T. Plank (1999), Dehydration and melting experiments constrain the fate of subducted sediments, Geochem. Geophys. Geosyst., 1(1), doi:10.1029/ 1999GC000014.

Kelly, R. K. (2003), Subduction dynamics at the Middle America Trench: New constraints from swath bathymetry, multichannel seismic data, and ${ }^{10} \mathrm{Be}$, Ph.D. thesis, 334 pp., Woods Hole Oceanogr. Inst., Mass. Inst. of Technol., Woods Hole, Mass.

Kimura, G., et al. (1997), Proceedings of the Ocean Drilling Program, Initial Reports, vol. 170, Ocean Drill. Program, College Station, Tex.

Leeman, W. P., and M. J. Carr (1995), Geochemical constraints on subduction processes in the Central American volcanic arc: Implications of boron geochemistry, in Geologic and Tectonic Development of the Caribbean Plate Boundary in Southern Central America, edited by P. Mann, Geol. Soc. Spec. Publ., 295, 57-73.

Leeman, W. P., M. J. Carr, and J. D. Morris (1994), Boron geochemistry of the Central American volcanic arc: Constraints on the genesis of subduction-related magmas, Geochim. Cosmochim. Acta, 58, 149-168.

Lesher, C. E. (1986), Effects of silicate liquid composition on mineral-liquid element partitioning from Soret diffusion studies, J. Geophys. Res., 91(B6), 6123-6141.

McIntosh, K. D., and M. K. Sen (2000), Geophysical evidence for dewatering and deformation processes in the ODP Leg 170 area onshore Costa Rica, Earth Planet. Sci. Lett., 178, $125-138$.

Meschede, M., P. Zweigel, and E. Kiefer (1999), Subsidence and extension at a convergent plate margin: Evidence for subduction erosion off Costa Rica, Terra Nova, 11, 112-117.

Miyashiro, A. (1974), Volcanic rock series in island arcs and active continental margins, Am. J. Sci., 274, 321-355.

Moritz, E., S. Bornholdt, H. Westphal, and M. Meschede (2000), Neural network interpretation of LWD data (ODP Leg 170) confirms complete sediment subduction at the Costa Rica convergent margin, Earth Planet. Sci. Lett., 174, 301-312.

Morris, J. D., W. P. Leeman, and F. Tera (1990), The subducted component in island arc lavas: Constraints from $\mathrm{Be}$ isotopes and Be-B systematics, Nature, 344, 31-36.

Morris, J. D., R. Valentine, and T. Harrison (2002), ${ }^{10} \mathrm{Be}$ imaging of sediment accretion and subduction along the northeast
Japan and Costa Rica convergent margins, Geology, 30, 5962.

Morris, J. D., et al. (2003), Proceedings of the Ocean Drilling Program, Initial Reports [CD-ROM], vol. 205, Ocean Drill. Program, College Station, Tex.

Neilson, C. H., and H. Sigurdsson (1981), Quantitative methods for electron microprobe analysis of sodium in natural and synthetic glasses, Am. Mineral., 66, 547-552.

Patino, L. C., M. J. Carr, and M. D. Feigenson (2000), Local and regional variations in Central American arc lavas controlled by variations in subducted sediment input, Contrib. Mineral. Petrol., 138, 265-283.

Pearce, J. A. (1983), Role of the sub-continental lithosphere in magma genesis at active continental margins, in Continental Basalts and Mantle Xenoliths, edited by C. J. Hawkesworth and M. J. Norry, pp. 230-249, Shiva, San Ramon, Calif.

Peccerillo, A., and S. R. Taylor (1976), Geochemistry of Eocene calcalkaline volcanic rocks from Kastamonu area, northern Turkey, Contrib. Mineral. Petrol., 58, 63-81.

Ranero, C. R., R. von Huene, E. Flueh, M. Duarte, D. Baca, and K. McIntosh (2000), A cross section of the convergent Pacific margin of Nicaragua, Tectonics, 19(2), 335357.

Reagan, M., J. Morris, E. Herrstrom, and M. Murrell (1994), Uranium series and beryllium isotopic evidence for an extended history of subduction modification of the mantle below Nicaragua, Geochim. Cosmochim. Acta, 58, 41994212.

Ruepke, L., J. Phipps-Morgan, M. Hort, and J. Conolly (2002), Are the regional variations in Central American arc lavas due to differing basaltic versus peridotitic slab sources of fluids? Geology, 30, 1035-1038.

Ryan, J. G. (1989), The systematics of lithium, beryllium and boron in young volcanic rocks, Ph.D. thesis, 326 pp., Columbia Univ., New York.

Ryan, J. G., and C. H. Langmuir (1987), The systematics of lithium abundances in young volcanic rocks, Geochim. Cosmochim. Acta, 51, 1727-1741.

Ryan, J. G., and C. H. Langmuir (1993), The systematics of boron abundances in young volcanic rocks, Geochim. Cosmochim. Acta, 57, 1489-1498.

Sano, T., T. Hasenaka, A. Shimaoka, C. Yonezawa, and T. Fukuoka (2001), Boron contents of Japan Trench sediments and Iwate basaltic lavas, Northeast Japan arc: Estimation of sediment-derived fluid contribution in mantle wedge, Earth Planet. Sci. Lett., 186, 187-198.

Seyfried, W. E.Jr., X. Chen, and L. H. Chan (1998), Trace element mobility and lithium isotope exchange during hydrothermal alteration of seafloor weathered basalt: An experimental study at $350^{\circ} \mathrm{C}, 500$ bars, Geochim. Cosmochim. Acta, 62, 949-960.

Shipley, T. H., K. D. McIntosh, E. A. Silver, and P. L. Stoffa (1992), Three-dimensional imaging of the Costa Rica accretionary prism: Structural diversity in a small volume of the lower slope, J. Geophys. Res., 97, 4439-4459.

Sinton, C. W., R. A. Duncan, and P. Denyer (1997), Nicoya Peninsula, Costa Rica: A single suite of Caribbean oceanic plateau magmas, J. Geophys. Res., 102, $15,507-15,520$.

Sun, S.-S., and W. F. McDonough (1989), Chemical and isotopic systematics of oceanic basalts: Implications for mantle composition and processes, in Magmatism in the Ocean Basins, edited by A. D. Saunders and M. J. Norry, Geol. Soc. Spec. Publ., 42, 313-346.

Tatsumi, Y., and H. Isoyama (1988), Transportation of beryllium with $\mathrm{H}_{2} \mathrm{O}$ at high pressures: Implication for magma 
genesis in subduction zones, Geophys. Res. Lett., 15, 180183.

Tatsumi, Y., M. Sakuyama, H. Fukuyama, and I. Kushiro (1983), Generation of arc basalt magmas and thermal structure of the mantle wedge in subduction zones, J. Geophys. Res., 88, 5815-5825.

Tomascak, P. B., F. Tera, R. T. Helz, and R. J. Walker (1999), The absence of lithium isotope fractionation during basalt differentiation: New measurement by multicollector sector ICP-MS, Geochim. Cosmochim. Acta, 63, 907-910.

Tomascak, P. B., J. G. Ryan, and M. J. Defant (2000), Lithium isotope evidence for light element decoupling in Panama subarc mantle, Geology, 28, 507-510.

Valentine, R., J. D. Morris, and D. Duncan (1997), Sediment subduction, accretion, underplating, and arc volcanism along the margin of Costa Rica: Constraints from $\mathrm{Ba}, \mathrm{Zn}, \mathrm{Ni}$ and ${ }^{10} \mathrm{Be}$ concentrations, Eos Trans. AGU, 78(46), Fall Meet. Suppl, F673.
Vannucchi, P., D. W. Scholl, M. Meschede, and K. McDougallReid (2001), Tectonic erosion and consequent collapse of the Pacific margin of Costa Rica: Combined implications from ODP Leg 170, seismic offshore data, and regional geology of the Nicoya Peninsula, Tectonics, 20(5), 649668.

Vannucchi, P., C. R. Ranero, S. Galeotti, S. M. Straub, D. W. Scholl, and K. McDougall-Reid (2003), Fast rates of subduction erosion along the Costa Rica Pacific margin: Implications for nonsteady rates of crustal recycling at subduction zones, J. Geophys. Res., 108(B11), 2511, doi:10.1029/ 2002JB002207.

von Huene, R., C. R. Ranero, W. Weinrebe, and K. Hinz (2000), Quaternary convergent margin tectonics of Costa Rica, segmentation of the Cocos Plate, and Central American volcanism, Tectonics, 19, 314-334.

You, C. F., and L. H. Chan (1996), Precise determination of lithium isotopic composition in low concentration natural samples, Geochim. Cosmochim. Acta, 60, 909-915. 